\section{Topical Phytotherapeutic Treatment: Management of Normalization of Elevated Levels of Biochemical Parameter During 0steoarthritic Disorders: A prospective Study}

\begin{abstract}
Background: C-reactive protein (CRP), creatine kinase-muscle (CK-MM) and aldolase A (AldoA) levels are proven to be realistic biochemical markers of osteoarthritic disorders (OADs). The aim of this study is to normalize the elevated levels of CRP, CK-MM and AldoA during OADs of knee-joints and degenerative changes in lumbarspine by topical application of phytoconstituents with specialized techniques.

Methods: Baseline data were collected and evaluated from 261 patients $(66.67 \%$ females) with OADs confirmed with radiological images. Serum CRP, CK-MM, and AldoA levels were measured at the baseline and at the end of six weeks of treatment using appropriate kits. All patients underwent a standardized physical, radiographic examinations and evaluation of risk factors (inflammation, muscle degeneration, bone erosion, and skeletal muscle diseases) by blood examination and completed a questionnaire. All the patients were treated with topical application of phytochemicals extracted from seven Indian medicinal plants mixed with virgin sesame oil and beehive-wax for a period of six-week with specialized techniques.

Results: The parameters of the risk factors for OADs at the end of six-week of treatment were highly significant $(\mathrm{p}<0.0001)$. The high and low ranges of all biomarkers, their percentage of improvements and Pearson's correlation coefficient were all highly significant $(p<0.0001)$. The improvements of pain, stiffness and daily functional activities at the end of treatment under KOOS, VAS, WOMAC index and KPS were highly significant $(p<0.0001)$ and also reduction of weight as evidenced by BMI $(p<0.0001)$ and radiological images as assessed by $\mathrm{K}$-L grading score.
\end{abstract}

Conclusions: It is firmly confirmed from the results that the elevated levels of CRP. CK-MM, and AldoA, represent the risks of inflammation, muscle degeneration, and skeletal muscle damage along with pain and all daily functional activities, body weight and radiological images as confirmed by above-mentioned international approved scales during OADs can be successful normalized by topical application of phytoconstituents within six-week with specialized treatment.

Keywords: Osteoarthritis repair; Biochemical markers: Phytomedicines; Phytoextracts; Phytochemicals; Medicinal plants; Topical phytotherapy

\section{Introduction}

The bone-joints disorders along with inflammation, damages of skeletal muscle, connective tissues, etc. collectively called as osteoarthritic disorders (OADs), which are extremely painful diseases worldwide [1-10]. OADs lead to degeneration in both knee joints, ankles, hip joint and vertebral column, etc. along with inflammation and muscular damages and these can be diagnosed on the basis of various parameters such as radio-imaging, anatomical, biochemical, haematological etc. and have already been established [3-17]. The tissues and cells specific abnormalities can easily be estimated in male and female adults with osteoarthrities [3-17].

\section{Journal of}

Orthopedics \& Rheumatology

\section{Apurba Ganguly ${ }^{1}$, Devika Ganguly ${ }^{1}$ and Sudip K Banerjee ${ }^{2}$}

${ }^{\prime}$ Department of Research and Development, OPTM Research Institute, India

${ }^{2}$ Department of Microbiology and Biotechnology, Techno India University, India

\section{*Address for Correspondence}

Apurba Ganguly, Founder and Head Researcher, OPTM Research Institute, 145 Rashbehari Avenue, Kolkata - 700029, India, Tel: +919830389616; Email: apurbaganguly15@gmail.com

Submission: 30 April, 2018

Accepted: 30 May, 2018

Published: 06 June, 2018

Copyright: () 2018 Ganguly A, et al. This is an open access article distributed under the Creative Commons Attribution License, which permits unrestricted use, distribution, and reproduction in any medium, provided the original work is properly cited.

In general, the elevated levels of serum C-reactive protein (CRP) in patients is found during inflammation, creatine kinasemuscle (CK-MM) due to muscular dystrophy, connective tissue damage, etc. and Aldolase A (AldoA) due to skeletal muscle or liver damage [18-27]. In this context, no synthetic medicines are found to normalize these elevated levels of biochemical parameters but topical phytotherapy are well-known to normalize these parameters supported by anatomical and radiological features [11,28-30]. Although, several phytomedicines are well-established for the curing of diseases and biochemical mechanisms of action by plant derived natural constituents such as phytochemicals have already been reported by several researchers [11,28-64].

Moreover, there are well-known guidelines for the standard clinical outcomes for pain and related parameters such as visual analogue scale (VAS), Western Ontario and McMaster Universities Osteoarthritis (WOMAC) Index, and Knee injury and Osteoarthritis Outcome Score (KOOS) used for assessing the effect of novel treatments on OADs by several researchers [65-67]. In case of gradation of narrowing of joint space, osteophytes lipping, sclerosis and deformity of bone contour under radiological investigation, the Kellgren-Lawrence grading scale is a common method to classify the severity of knee OA with the help of five grades (0-4) [68].

The present study attempted to normalize the risk factors in patients with OADs, such as inflammation, muscle degeneration, bone erosion, and skeletal muscle damage, by measuring the decreasing phenomenon of serum CRP, CK-MM, and AldoA levels along with controlling pain, maintaining joint flexibility, optimize joint and limb function and improving quality of life measured with the help of VAS scale, WOMAC index, KPS and KOOS by topical application of specific phytotherapeutic treatment protocol for six weeks correlated with knee radiographic diagnosis with the help of $\mathrm{K}-\mathrm{L}$ grading system. 


\section{Materials and Methods}

\section{Recruitment of patients}

Eight hundred sixty-four patients, aged 40 to 75 years old, from ten centres of OPTM Health Care (P) Ltd, Kolkata, Delhi, Mumbai and Pune, India from August 2016 to March 2017 were enrolled into this study. Initially, 468 patients (303 females and 165 males) out of 864 were selected, based on the sign, symptoms and radiological changes consisted with OA changes in right and left knee joints and degenerative changes in lumbar spine. The total of 261 patients suffering for more than five years (normally they report to the clinic) with medial tibiofemoral OA changes in right and left knee joints and degenerative changes in the lumbar spine were selected using exclusion criteria summarized in Table 1.

The study protocol was evaluated and approved by the OPTM Research Institute Ethics Committee. The institute is registered with the government. An Institutional Review Board-approved consent form for the physical examinations, blood sample collections and cervical spine, lumbar spine, hip and knee joint images (X-rays, CT scan or MRI) required for the study was signed by all patients in the first phase of the screening procedure.

\section{Study design}

After the analysis of exclusion criteria including discontinued (dropped out) patients, the balance of 261 ( 174 females and 87 males) patients with symptoms of visual inflammation, pain and restricted movements, symptomatic knee arthrosis, degenerative changes in lumber region according to the radiological analysis were finally involved in the study summarized in Figure 1. Separate evaluations were performed for subjects regarding various complaints and supplements taken to diminish pain or improve fitness. The present studied protocol has been designed to control pain, to maintain joint flexibility, to optimize joint and limb functions and to improve quality of life without any kinds of drug therapy such as acetaminophen, NSAIDs, including COX-2 inhibitors, corticosteroids and hyaluronic injections, glucosamine sulphate, chondroitin, calcium and other alternative treatments such as homeopathic, ayurvedic and hence patients were advised to stop using any kind of above-mentioned drug therapy one day prior to inclusion in the study. Each patient completed a questionnaire, providing details regarding demographics, medical history, nutritional status, ethnic barriers and work status at the baseline and summarized in Table 2 .

\section{Evaluation of biochemical parameters in blood}

A $5 \mathrm{ml}$ blood sample was collected in a plain vial from each patient with OAD before and after the treatment. Blood samples were then centrifuged at $1000 \mathrm{~g}$ for $10 \mathrm{~min}$ at $4{ }^{\circ} \mathrm{C}$ to obtain serum. Finally, the serum was used to analyse CRP, CK-MM, and AldoA levels for each

Table 1: Exclusion criteria during selection of patients

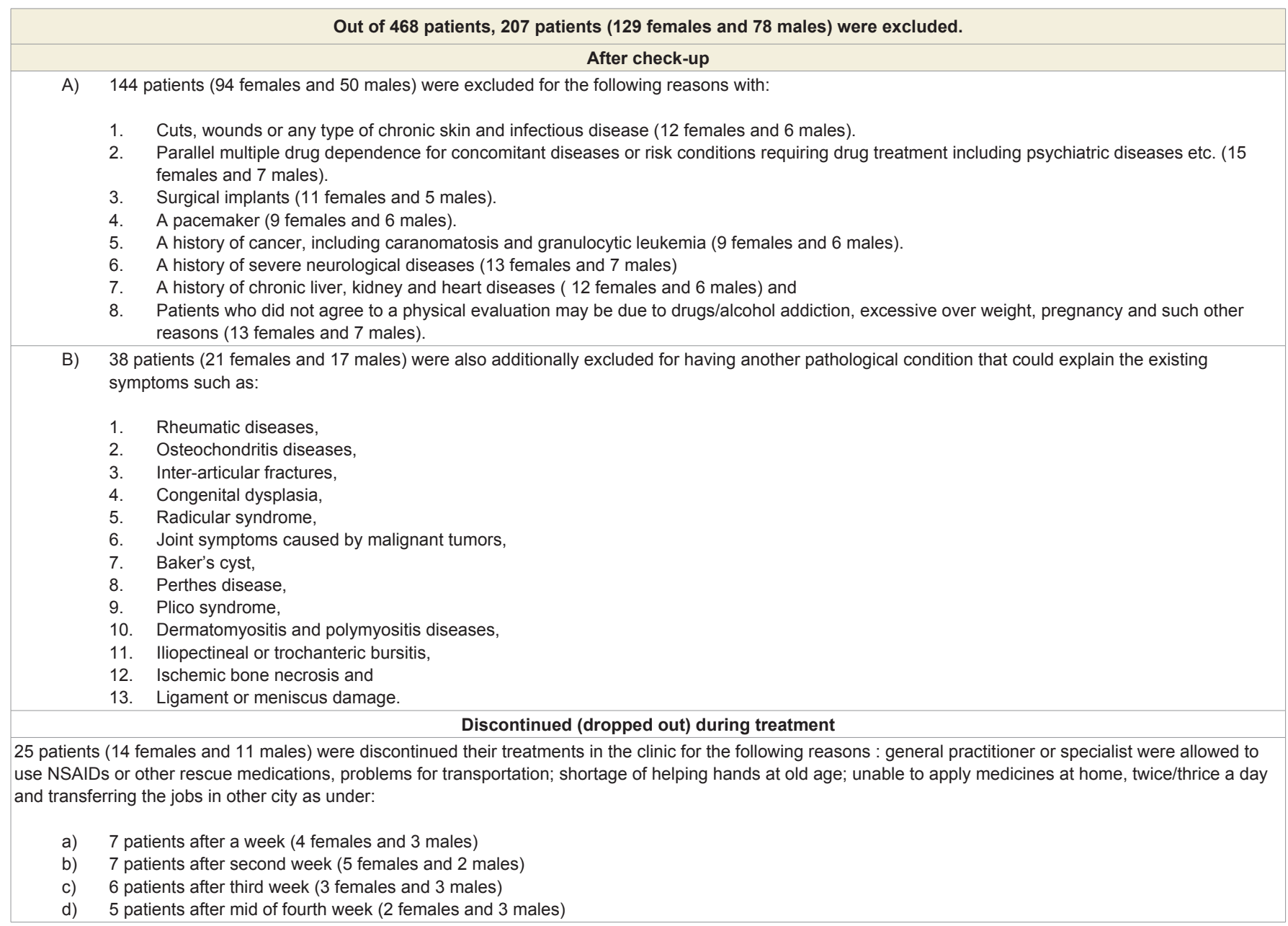




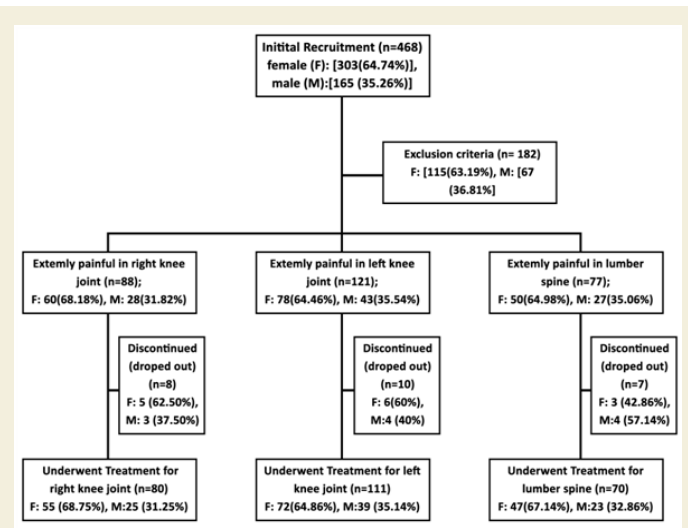

Figure 1: Flow chart of the patients who finally participated in this study.

patient at the baseline and at the end of six weeks of treatment. The biomarkers were rigorously analysed. Each test for each patient has been rechecked by the BS-240 Mindray fully automated biochemistry analyser before reporting the final test results at the baseline and after the treatment.

CRP levels (mg/L) were quantitatively assessed using a CRP LEIT kit and the latex-enhanced turbidimetric immune assay (Agappe Diagnostics Limited, India) at a wavelength of $578 \mathrm{~nm}$. The kit was developed based on the methods reported by Tillett WS et al., Ziegenhagen $\mathrm{G}$ et al. and Rifai $\mathrm{N}$ et al. [69-71]. CK-MM (U/L) levels were quantitatively assessed using a Creatine Kinase- MM kit (CK-MM/CPK-MM/CK-3) and an immunoassay (Aalto Scientific, Limited, USA). The kit was developed based on the methods reported by Cabaniss CD [72]. AldoA levels (U/L) were quantified using an ALDOLASE (ALS) RX MONZA AD 189 kit (Randox Laboratories Ltd, Antrim, UK) based on a photometric assay at a wavelength of $340 \mathrm{~nm}$. The kit was developed according to the method reported by Feissli S [73]. The subjects suffering from OADs with inflammation, muscle degeneration and skeletal muscle damage were studied to identify a specific biochemical parameter, such as CRP, CK-MM, and AldoA levels, in the affected population. All blood tests were conducted under the supervision of the Chief biochemist and the Chief pathologist in the Galaxy Medical Centre, an ISO 9001: 2015 certified lab with Registration No. L/004-(05)-15/0129 under the W.B Clinical Establishment Act 1950.

The mean, standard error of the mean (SEM) and their mean differences (MDs), 95\% confidence intervals (CIs), and p-values of the three biomarkers such as CRP, CK-MM and Aldo A were evaluated at the baseline and at the end of six weeks of treatment.

\section{Evaluations of the high and low ranges of biochemical parameters and their percentage of improvements}

The reference ranges of the three biomarkers are as follows: $\mathrm{CRP}<6 \mathrm{mg} / \mathrm{L}, \mathrm{CK}-\mathrm{MM}<168 \mathrm{U} / \mathrm{L}$ and AldoA<7.6 U/L. The 261 participants were divided into six categories according to the high and low ranges of the three biomarkers: $\mathrm{CRP}<6 \mathrm{mg} / \mathrm{L}$ and $\mathrm{CRP}>6$ $\mathrm{mg} / \mathrm{L} ; \mathrm{CK}-\mathrm{MM}<168 \mathrm{U} / \mathrm{L}$ and $\mathrm{CK}-\mathrm{MM}>168 \mathrm{U} / \mathrm{L}$; and Aldo $\mathrm{A}<7.6 \mathrm{U} / \mathrm{L}$ and Aldo $\mathrm{A}>7.6 \mathrm{U} / \mathrm{L}$. The number of patients and their percentages in the high and low ranges of the three biomarkers such as $\mathrm{CRP}<6 \mathrm{mg} / \mathrm{L}$,
Table 2: Demographic data and baseline characteristics of the study subjects.

\begin{tabular}{|c|c|c|c|}
\hline Characteristic & Combined & Female & Male \\
\hline No of subjects (\%) & 261 & $174(66.67)$ & $87(33.33)$ \\
\hline Mean age $(S D)$ in years & $56.93(12.21)$ & $56.14(10.74)$ & $58.49(14.66$ \\
\hline Mean weight (SD) in $\mathrm{kg}$ & $85.33(6.31)$ & $84.12(5.21)$ & $87.75(7.52)$ \\
\hline Mean height (SD) in meter & $1.53(0.91)$ & $1.67(0.88)$ & $1.71(0.93)$ \\
\hline Mean BMI (SD) in kg/m² & $30 . .10(7.73)$ & $30.15(8.17)$ & $30.01(6.77)$ \\
\hline $\begin{array}{l}\text { Mean symptom duration in years } \\
\text { (SD) }\end{array}$ & $7.89(1.90)$ & $7.78(1.78)$ & $8.12(2.11)$ \\
\hline \multicolumn{4}{|c|}{ Indian ethnic group (\%) } \\
\hline Bengali & $95(36.40)$ & $68(39.08)$ & $27(31.03)$ \\
\hline Gujrati & $25(9.58)$ & $17(9.77)$ & $8(9.20)$ \\
\hline Marwaree & $22(8.43)$ & $13(7.47)$ & $9(10.34)$ \\
\hline Marathi & $21(8.05)$ & $14(8.05)$ & $7(8.05)$ \\
\hline Tamil & $19(7.28)$ & $9(5.17)$ & $10(11.49)$ \\
\hline Punjabi & $29(11.11)$ & $21(12.07)$ & $8(9.20)$ \\
\hline Shindhi & $27(10.34)$ & $17(9.77)$ & $10(11.49)$ \\
\hline North East India & $23(8.81)$ & $15(8.62)$ & $8(9.20)$ \\
\hline \multicolumn{4}{|c|}{ Dietary habits (\%) } \\
\hline Vegetarian & $97(37.16)$ & $58(33.33)$ & $39(44.83)$ \\
\hline Non- vegetarian & $164(62.84)$ & $116(66.67)$ & $48(55.17)$ \\
\hline \multicolumn{4}{|c|}{ Other habits } \\
\hline Smoking & $51(19.54)$ & $19(10.92)$ & $32(36.78)$ \\
\hline Drinking alcohol & $53(20.31)$ & $22(12.64)$ & $21(26.92)$ \\
\hline Drinking tea and coffee & $66(25.29)$ & $34(19.54)$ & $32(41.03)$ \\
\hline Chewing tobacco & $37(14.18)$ & $16(9.19)$ & $11(14.10)$ \\
\hline
\end{tabular}
Analysis of radiological reports (\%)

\begin{tabular}{|l|l|l|l|}
\hline KOA in right knee with osteophytes & $261(100)$ & $174(100)$ & $84(100)$
\end{tabular}

\begin{tabular}{|l|l|l|l|}
\hline KOA in left knee with osteophytes & $261(100)$ & $174(100)$ & $84(100)$
\end{tabular}

\begin{tabular}{|c|c|c|c|}
$\begin{array}{c}\text { Degenerative changes in lumber } \\
\text { region }\end{array}$ & $70(26.82)$ & $47(27.01)$ & $23(26.44)$
\end{tabular}

\begin{tabular}{|c|c|c|c|}
\hline \multicolumn{4}{|c|}{ Work status (\%) } \\
\hline Employed fulltime & $50(19.16)$ & $12(6.90)$ & $38(48.72)$ \\
\hline Employed part time & $7(2.68)$ & $4(2.30)$ & $3(3.85)$ \\
\hline Housewife / Home- maker & $104(39.85)$ & $104(59.77)$ & - \\
\hline Retired & $32(12.26)$ & $13(7.47)$ & $19(24.36)$ \\
\hline Self employed & $68(26.05)$ & $41(23.56)$ & $27(34.61)$ \\
\hline \multicolumn{4}{|c|}{ Marital status (\%) } \\
\hline Single & $8(3.06)$ & $3(1.72)$ & $5(6.41)$ \\
\hline Married & $185(70.88)$ & $128(73.56)$ & $57(73.08)$ \\
\hline Separated & $12(4.60)$ & $7(4.02)$ & $5(6.41)$ \\
\hline Divorced & $21(8.04)$ & $13(7.47)$ & $8(10.26)$ \\
\hline Widowed & $35(13.41)$ & $23(13.22)$ & $12(15.38)$ \\
\hline
\end{tabular}

Multiple complaints or comorbidities (\%)

\begin{tabular}{|c|c|c|c|}
\hline \multicolumn{5}{|c|}{ Multiple complaints or comorbidities (\%) } \\
\hline Constipation & $251(96.17)$ & $173(99.42)$ & $76(97.43)$ \\
\hline Acidity and reflux & $247(94.64)$ & $164(94.25)$ & $83(95.40)$ \\
\hline Insomnia & $212(81.23)$ & $143(82.18)$ & $69(79.31)$ \\
\hline Varicose veins & $191(73.18)$ & $149(85.63)$ & $42(48.27)$ \\
\hline Urinary incontinence & $113(43.29)$ & $44(25.29)$ & $69(79.31)$ \\
\hline Crepitus during knee flexion & $171(65.52)$ & $118(67.82)$ & $53(60.92)$ \\
\hline Morning stiffness (<30 min.) & $239(91.57)$ & $162(62.07)$ & $77(88.50)$ \\
\hline
\end{tabular}

$\mathrm{CRP}>6 \mathrm{mg} / \mathrm{L}, \mathrm{CK}-\mathrm{MM}<168.0 \mathrm{U} / \mathrm{L}, \mathrm{CK}-\mathrm{MM}>168.0 \mathrm{U} / \mathrm{L}$, Aldo $\mathrm{A}<7.6$ $\mathrm{U} / \mathrm{L}$ and Aldo $\mathrm{A}>7.6 \mathrm{U} / \mathrm{L}$ were studied. The mean, standard error of the mean (SEM) and their mean differences (MDs), 95\% confidence intervals (CIs), and p-values of the three biomarkers in the high and low ranges were evaluated at the baseline and at the end of six weeks of treatment. 
Citation: Ganguly A, Ganguly D, Banerjee SK. Topical Phytotherapeutic Treatment: Management of Normalization of Elevated Levels of Biochemical Parameter During Osteoarthritic Disorders: A prospective Study. J Orthopedics Rheumatol. 2018; 5(1): 14

\section{Evaluation of Pearson's correlation coefficients among two biomarkers}

The Pearson's correlation coefficients among two biochemical markers such as CRP at the baseline $\left(\mathrm{CRP}^{\mathrm{b}}\right)$ and CK-MM after the treatment $\left(\mathrm{CK}-\mathrm{MM}^{\mathrm{t}}\right), \mathrm{CRP}$ at the baseline $\left(\mathrm{CRP}^{\mathrm{b}}\right)$ and Aldo $\mathrm{A}$ after the treatment $\left(\right.$ Aldo $\left.^{t}\right), C K-M M$ at the baseline $\left(C K-M^{\mathrm{b}}\right)$ and AldoA after the treatment $\left(\right.$ Aldo $\left.^{t}\right)$, CRP at the baseline $\left(\mathrm{CRP}^{\mathrm{b}}\right)$ and CRP after the treatment $\left(\mathrm{CRP}^{\mathrm{t}}\right), \mathrm{CK}-\mathrm{MM}$ at the baseline $\left(\mathrm{CK}-\mathrm{MM}^{\mathrm{b}}\right)$ and $\mathrm{CK}-\mathrm{MM}$ after the treatment $\left(\mathrm{CK}-\mathrm{MM}^{\mathrm{t}}\right)$, and AldoA at the baseline $\left(\right.$ Aldo $^{\mathrm{b}}$ ) and AldoA after the treatment (Aldo $\mathrm{A}^{\mathrm{t}}$ ) were studied.

\section{Evaluation of KOOS knee survey}

The five separately scored subscales such as pain, other symptoms (swelling, restricted range of motion and mechanical symptoms), function in daily living (disability on the level of daily activities), function in sport and recreation (disability on a level physically more demanding than activities of daily living) and knee-related quality of life (quality of life, mental and social aspects such as awareness and lifestyle changes) under Knee-injury Osteoarthritis Outcomes Scale (KOOS) developed by Ewa Roos and co-authors in the 1990s to assess the patient's opinion about their knee and associated problems as an instrument were evaluated at the baseline and at the end of six weeks of treatment for all the patents.

\section{Evaluation of pain under Visual analogue scale (VAS)}

Observation of patient's perceived symptoms of pain intensity was point out on the line of $100 \mathrm{~mm}$. Their pain intensity marked as no pain (0-4), mild pain (5-44), moderate pain (45-74) and severe pain (75-100) separately on right leg, left leg and lower back pain under Visual analogue scales (VAS) were evaluated before and after the treatment and their percentage of improvement were also evaluated.

\section{Evaluation of WOMAC osteoarthritis Index}

The assessment of pain, stiffness and physical functional disabilities of each patient were evaluated for all females and males separately using The Western Ontario McMaster Universities Osteoarthritis Index (WOMAC Index) developed by Bellamy $\mathrm{N}$ et al. [66] at the baseline and end of 6-week and their percentage of improvement were studied.

\section{Evaluation of the Karnofsky performance status (KPS) scale}

Karnofsky performance status (KPS) score is used to determine a patient's prognosis to carry out daily activities. A higher score indicates the patient is better able to carry out daily activities and its range from 0 to 100. The KPS is evaluated for each patient at the baseline and at the end of treatment. The percentages of improvements were evaluated at the end of the treatment for all the patents separately. Their mean, SD and p-values for overall and separately by gender were studied.

\section{Evaluation of Body mass index (BMI)}

Body weight in kilogram was measured without shoes or heavy clothing using an electronic scale. Height in meter was measured without shoes using a wall-mounted stadiometer. Body mass index $\left(\mathrm{BMI}, \mathrm{kg} / \mathrm{m}^{2}\right.$ ) was calculated for all the patients based on measured weights and heights at the baseline and at the end of 6 weeks of treatment. The percentages of improvements were evaluated at the end of treatment for all the patents separately.
Evaluation of radiological images with the Kellygren and Lawrance system

The Kellgren and Lawrance system is a common method of classifying the severity of knee osteoarthritis (OA) developed by Kellgren JH et al [68]. The KL classification was originally described using anterior-posterior (AP) knee radiographs based on the five grades such as Grade 0, which demonstrates no radiographic features of OA present; Grade 1, which demonstrates doubtful joint space narrowing (JSN) with possible osteophyte lipping; Grate 2, which demonstrates possible JSN with definite osteophyte formation; Grade 3, which demonstrates definite JSN, moderate osteophyte formation, some sclerosis and possible deformity of bony ends and Grade 4, which demonstrates large osteophyte formation, severe JSN with marked sclerosis and definite deformity of bony ends. Radiological images for both knee joints and lumbo-sacral spine of 261 combined patients were collected at baseline and at the end of six weeks of treatment evaluations The KL classification of AP knee radiographs of all patients were evaluated at the baseline and at the end of 6-week treatment.

The AP knee and lumbar vertebrae X-ray images of two such patients, before and after the treatment are depicted in Figure 2A-2B.

Evaluation of Indian medicinal plants, their phytoconstituants from aqueous extracts and their established mechanisms of action used in the treatment protocol

The treatment involves topical application of phytoconstituents from the extracts of seven Indian medicinal plants namely Cissus quadrangularis (whole plant), Calotropis gigantea (root and leaves), Zingiber officinalis (rhizome), Rosemarinus officinalis (leaves and flowers), Boswellia serratia (resin), Curcuma longa (rhizome) and Withania somnifera (root) mixed with virgin sesame oil (extracted from seeds at room temperature) and beehives wax to make viscous phyto-based oil without using any preservatives or chemicals in order to preserve the phytochemical properties of plants intact [31-64]. The virgin sesame oil is acted as bio-preservative and beehive-wax helps to reduce joint pain, to relieve stiffness, to stimulate circulation and to moisturize skin [57-64]. Several researchers had already reported the medical effects (specially on pain, inflammation and stiffness of muscles) on human body of the phytochemicals contained in Cissus

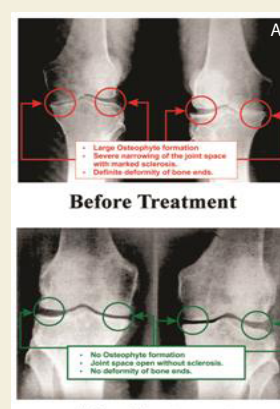

After Treatment

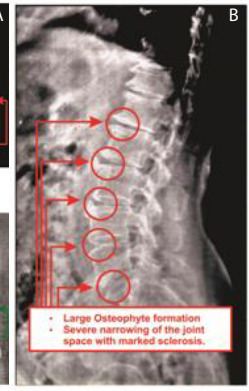

Before Treatment

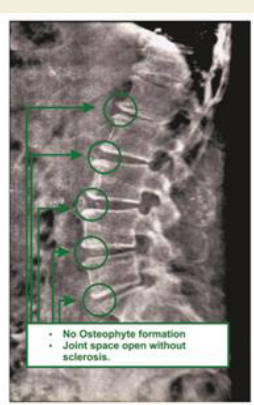

After Treatment
Figure 2: A: AP view of X-rays, out of 261 patients, showing before and after the treatment of knee joints with Phytotherapy. 2B: AP view of X-rays, out of 70 patients, showing before and after the treatment of L.S spine with Phytotherapy. 
Citation: Ganguly A, Ganguly D, Banerjee SK. Topical Phytotherapeutic Treatment: Management of Normalization of Elevated Levels of Biochemical Parameter During Osteoarthritic Disorders: A prospective Study. J Orthopedics Rheumatol. 2018; 5(1): 14

quadrangularies, Rosemarinus officinals, Calotropis gigantea, Zingiber officinalis, Boswellia serrata, Curcuma longa, Withania somnifera and Sesamum indicum and their mechanism of actions is shown in Table 3 [31-64].

\section{Objectives and phytotherapeutic treatment procedure as a whole}

The main objectives of the treatment are: to reduce pain, inflammation and stiffness of muscles without dependence upon any types of pain killers or corticosteroid injection or arthrocentesis; to increase the muscular strength without using supporting belt on the waist or knee joints and the gaps between the bones/vertebrae; to rectify calcifications/degeneration of bones; and to normalize the varus/valgus deformities and elevated levels of biochemical parameters such as CRP,CK-MM and Aldo A occurred during OADs $[8,9,11,28,29]$. The treatment protocol is based on well-defined certain principles and theories and also based on the applications of wellknown chemical, mechanical, thermal and electrical stimuli which improve the fundamental properties of all muscles such as excitability, conductivity, contractibility, elasticity and viscosity $[8,9,11,28,29]$. Each $30 \mathrm{ml}$ of said viscous phyto-based oil prepared from the extracts of seven Indian medicinal plants mixed with virgin sesame oil and beehive-wax is to be applied with the tip of three fingers in particular technique over the skin three times a day with minimum interval of two hours for six weeks ; lying in six different postural positions such as supine, prone, right and left contra-lateral and right and left cross (supper) contra-lateral in different programmed sequences in order to nourished the effected group of badly damaged muscles and nerves in the legs and lumber regions during OAD (Table 4) [8,9,11,28,29].

To achieve the ultimate objectives of the treatment, the period

Table 3: Medicinal plant species usage for therapy through biochemical mechanism in OAD patients.

\begin{tabular}{|c|c|c|c|c|}
\hline $\begin{array}{l}\text { Plant species } \\
\text { (Parts used) }\end{array}$ & Phytochemicals & Biochemical mechanism of action & Disease prevention & References \\
\hline $\begin{array}{l}\text { Cissus } \\
\text { quadrangularis } \\
\text { (Whole plant) }\end{array}$ & $\begin{array}{l}\text { Lupenone, epifriedlinol, isoaroborenol and } \beta \text {-sitosterol, } \delta \text {-amyrin } \\
\text { acetate, aliphatic acid hexadecanoic acid, stilbene glucoside } \\
\text { transresveratrol-3-O-glucoside. Other compounds namely, } \\
\delta \text { - amyrone, } \delta \text {-amyrin, } \beta \text {-sitosterol, kaempferol, quercetin and } \\
\text { resveratrol, quadrangularin A, pallidol, quercitin, quercitrin, beta- } \\
\text { sitosterol and betasitosterol glycoside }\end{array}$ & $\begin{array}{l}\text { Stimulation of metabolism and increased } \\
\text { uptake of the minerals calcium, sulphur } \\
\text { and strontium. decrease in superoxide } \\
\text { dismutase (SOD), catalase (CAT), } \\
\text { glutathione peroxidase (GPX) and } \\
\text { reduced glutathione (GSH) }\end{array}$ & $\begin{array}{l}\text { Anti-osteoporotic, bone fracture } \\
\text { repair, bone healing, antioxidant, } \\
\text { analgesic and anti-inflammatory } \\
\text { activity, antiobesity property, } \\
\text { activity, Central nervous system } \\
\text { activity }\end{array}$ & [1-11] \\
\hline $\begin{array}{l}\text { Calotropis } \\
\text { gigantean } \\
\text { (Root and } \\
\text { leaves) }\end{array}$ & $\begin{array}{l}\text { Alkaloids and glycosides, saponins, flavonoids in root and steroids, } \\
\text { triterpenoids, glycosides, flavonoids, carbohydrates, proteins in } \\
\text { leaves }\end{array}$ & $\begin{array}{c}\text { Decreased SOD and CAT, also } \\
\text { decreasing the activity of 3-hydroxyl-3- } \\
\text { methly-glutaryl coenzymes A reductase } \\
\text { (HMG CoA reductase) an enzyme of } \\
\text { cholesterol biosynthesis }\end{array}$ & $\begin{array}{c}\text { Antimicrobial, anti-arthritic, } \\
\text { muscle mass and strength, anti- } \\
\text { inflammatory }\end{array}$ & [12-14] \\
\hline $\begin{array}{l}\text { Zingiber } \\
\text { officinalis } \\
\text { (Rhizome) }\end{array}$ & $\begin{array}{c}\text { Terpene including } \\
\text { zingiberene, } \beta \text {-bisabolene, } \alpha \text {-farnesene, } \beta \text {-sesquiphellandrene, } \\
\text { and } \alpha \text {-curcumene, while phenolic compounds include gingerol, } \\
\text { paradols, and shogaol, gingerols and shogaol }\end{array}$ & $\begin{array}{l}\text { inhibiting COX-1, COX-2 and LOX, } \\
\text { increasing synthesis of pro-inflammatory } \\
\text { cytokines (TNF- } \alpha \text { ), IL-6, and monocyte } \\
\text { chemotactic protein-1), hs-CRP and } \\
\text { TNF- } \alpha \text { lowering }\end{array}$ & $\begin{array}{l}\text { anti-inflammatory effects, pain } \\
\text { relief, anti-arthritis }\end{array}$ & [15-22] \\
\hline $\begin{array}{l}\text { Rosmarinus } \\
\text { officinalis } \\
\text { (Leaves and } \\
\text { flower) }\end{array}$ & $\begin{array}{c}\text { Essential oil, camphor, 1,8-cineole, pinene, borneol, } 297 \text { camphene, } \\
\text { pineneand limonene, phenolic compounds, rosmarinic, chlororenic } \\
\text { and caffeic acids. Tricyclic diterpenes such as rossmaridiphenol, } \\
\text { carnosol, carnosic acid and rosmanol, and diterpenes, including } \\
\text { seco-hinokio }\end{array}$ & $\begin{array}{c}\text { Mitochondria, microsomes and red } \\
\text { blood cell membrane against oxidative } \\
\text { stress, other possible mechanism is that } \\
\text { extract could inhibit CYP2E1 }\end{array}$ & $\begin{array}{l}\text { Arthritis, bruises, eczema, gout, } \\
\text { muscular pain, neuralgeia, } \\
\text { revitalizing paralysed limbs, } \\
\text { rheumatism, rheumatoid arthritis, } \\
\text { sciatica, scrofulous sores, etc. }\end{array}$ & {$[23,24]$} \\
\hline $\begin{array}{c}\text { Boswellia } \\
\text { serrata (Resin) }\end{array}$ & $\begin{array}{l}\text { oleo-resin, 11-keto- } \beta \text {-boswellic acid, } d \text { - } \alpha \text {-thujene, } \alpha \text {-pinene, } \\
\text { p-cymene and d-limonene etc. }\end{array}$ & $\begin{array}{l}\text { COX-2 inhibitor, PGE1-S, cathepsin G, } \\
\text { LOX-5, MMP-9, MMP-13, NO, PGE1, } \\
\text { TNF- } \alpha, \text { IL-1, IL-2, IL-4, IL-6, IFN- }\end{array}$ & $\begin{array}{l}\text { Anti-arthritic, hypolipidemic, } \\
\text { immunomodulatory, analgesic, } \\
\text { muscle Relaxant activity, } \\
\text { antiinflammatory }\end{array}$ & $\begin{array}{l}{[22,24,} \\
25]\end{array}$ \\
\hline $\begin{array}{l}\text { Curcuma longa } \\
\text { (Rhizome) }\end{array}$ & $\begin{array}{l}\text { ar-turmerone, } \beta \text {-sesquiphellandrene, curcuminol, } 2 \text {-methoxy-4- } \\
\text { vinylphenol, cis- } \beta \text {-elemenone, isolongifolol, geranyl-pcumene, } \\
\beta \text {-turmerone, } \beta \text {-curcumene, } \beta \text {-vatirenene, } \beta \text {-caryophyllene, } \\
\alpha \text {-curcumene, furanodiene, } \gamma \text {-curcumene, } \alpha \text {-turmerone and } \\
\alpha \text {-cedrene }\end{array}$ & $\begin{array}{l}\text { COX-2 inhibitor, (+) SOD, GSH, (-) } \\
\text { MDA (HS) }\end{array}$ & $\begin{array}{l}\text { Anti-arthritic, anti-inflammatory, } \\
\text { anti-proliferative, osteoclast- } \\
\text { osteoblast balance }\end{array}$ & [25] \\
\hline $\begin{array}{l}\text { Withania } \\
\text { somnifera } \\
\text { (Root) }\end{array}$ & Carbohydrates, glycosides, steroids, saponins etc. & $\begin{array}{l}\text { Liposaccharide-S induced synthesis of } \\
\text { pro-inflammatory cytokines (TNF- } \alpha \text {, IL- } \\
1 \beta \text { and IL-12) in peripheral and synovial } \\
\text { fluid mononuclear cells from rheumatoid } \\
\text { arthritis (in vitro), NF kBsubjects in vitro, } \\
\text { (-)TNF- } \alpha, \text { IL-1 } 1 \beta, \text { IL-12, collagenase }\end{array}$ & $\begin{array}{l}\text { Anti-bacterial, Anti-oxidant, anti- } \\
\text { Inflammation and analgesic, } \\
\text { scores for pain, stiffness and } \\
\text { disability }\end{array}$ & {$[25,26]$} \\
\hline \begin{tabular}{c|} 
Sesamum \\
indicum (Seed)
\end{tabular} & & $\begin{array}{c}\text { lower plasmatic levels of thiobarbituric } \\
\text { acid reactive substances and reduced } \\
\text { gamma-glutamyl-transferase activity in } \\
\text { the jointsand spleen, lowering the levels } \\
\text { of IL-1 } \beta, \text { IL-6), and of high-sensitivity } \\
\text { C-reactive protein (hs-CRP) and IL- } \\
\text { 6impeding the activity of nuclear factor- } \\
\text { KB (NF-KB), decreasing serum levels of } \\
\text { malondialdehydeinflammatory mediators } \\
(T N F-\alpha)\end{array}$ & $\begin{array}{l}\text { Anti-arthritis, anti-inflammatory } \\
\text { in joints, protect bone loss and } \\
\text { cartilage degradation }\end{array}$ & $\begin{array}{r}{[[25,27,} \\
28-31]\end{array}$ \\
\hline $\begin{array}{l}\text { Beehive wax } \\
\text { (Wax) }\end{array}$ & $\begin{array}{c}\text { Heptacosane, nonacosane, hentriacontane, pentacosane and } \\
\text { tricosane, free fatty alcohols, monoesters and hydroxymonoesters, } \\
\text { palmitic, 15-hydroxypalmitic and oleic acids, palmitic, } \\
\text { 15-hydroxypalmitic and oleic acids }\end{array}$ & Not studied & $\begin{array}{l}\text { Anti-inflammatory, osteoarthritis } \\
\text { symptoms control, anti-microbial }\end{array}$ & [32-35] \\
\hline
\end{tabular}


Table 4: Showing improvement of radiological images of 261 combined-sex patients before and after the treatment under the Kellgren-Lawrance Grading Scale.

Grade 0: no radiographic features of OA present; Grade 1: doubtful joint space narrowing (JSN) with possible osteophyte lipping; Grate 2: possible JSN with definite osteophyte formation; Grade 3:definite JSN, moderate osteophyte formation, some sclerosis and possible deformity of bony ends and Grade 4 large osteophyte formation, severe JSN with marked sclerosis and definite deformity of bony ends.

\begin{tabular}{|l|c|c|c|c|c|c|c|c|c|}
\hline \multirow{2}{*}{ Grade } & \multicolumn{4}{|c|}{ Baseline } & \multicolumn{4}{c|}{ End of treatment } \\
\cline { 2 - 11 } & Right leg & $\%$ & Left leg & $\%$ & Right leg & $\%$ & Left leg & $\%$ \\
\hline Grade 1 & None & & None & & 246 & 94.25 & 244 & 93.49 \\
\hline Grade 2 & None & & None & & 15 & 5.75 & 17 & 6.51 \\
\hline Grade 3 & 80 & 30.65 & 69 & 26.44 & None & & None & \\
\hline Grade 4 & 181 & 69.35 & 192 & 73.56 & None & & None & \\
\hline
\end{tabular}

of treatment has been fixed for six weeks, three sessions a day. One session in the clinic and two sessions a day with a minimum interval of two hours in the house or thirteen weeks at home (three sessions a day with a minimum interval of two hours). In the clinic, after the application of phytochemicals contained paste with the help of wooden device (WD) and tip of three fingers, number of medicated fomentation devices (MFDs) with control temperature at $106^{\circ} \mathrm{F}$ were rapped from the origins to the insertions over the muscles affecting the movement of knee joints and lower spine in different postural positions such as supine, prone, right and left contra-lateral and right and left cross contra-lateral in the first phase of treatment $[8,9,11,28,29]$. In the second phase of treatment, a computerized muscle stimulator operated with battery of 9-volt DC was applied over the various connective tissues through the skin for a maximum period of 5 to 10 minutes. These helped to disperse the coagulated blood or effusions might be present in the affected areas of OAD patients. In the house treatment of thirteen weeks, only phytochemicals contained paste with the help of wooden device and tip of three fingers is to be applied, three sessions a day with programmed sequences of different postural positions supplied in advanced according to the conditions of OAD of the patients $[8,9,11,28,29]$. Each patient has been requested to visit the clinic for review in every week. Sometimes depending upon the severity of the pain as well as condition of the deformities, the sequence of the programmed postural positions was altered restricted to two positions in a session. Based on observations for optimum results had tried on more than thousand patients, the maximum period of treatment had been fixed for six weeks (one session in the clinic or two sessions in the house with two-hourly interval) or thirteen weeks at home (three sessions a day with a minimum interval of two hours) $[9,11,28,29]$.

\section{External study reviewers}

All results and data before and after the treatment were evaluated by an external reviewing panel consisting of two biochemists, a biostatistician, a radiologist, and a general medical practitioner, none of whom were in contract with the patients.

\section{Data collection and Statistical analysis}

Data were summarized using descriptive statistics for continuous variables (e.g. mean, standard error of the mean, $\mathrm{N}$, minimum, maximum), frequency tables, or proportions for discrete variables, and $95 \%$ confidence intervals. Statistical analyses were done by using software (Graph Pad Prism, Version 5.0) with repeated measures for student-t test to determine significant values at $\mathrm{p}<0.05$ level along with $\mathrm{r}$ (Pearson's correlation coefficient) values to determine strong and weak correlation among two variables for measuring different improvement parameters of OAD patients for combinedsex patients, females and males separately. The comparison was done between baseline and after six weeks of phytotherapeutic treatment.

\section{Results}

\section{Patients enrollment and baseline characteristics}

A total of 468 patients (68.74\% females) those who were suffering with OAD confirmed by X-ray or MRI were included in this study. Figure 1 shows the flow chart of the 261 combined-sex patients (178 females and 78 males) who were finally participated with specific areas of pain in this study after exclusion of 207 patients (Table 1). Table 2 displays the baseline demographic characteristics of all patients. The patients were not being treated by oral medications; injections and any type of alternative interventions such as homeopathic, ayurvedic, natural and herbal treatments for diminishing pain or inflammation, for muscle relaxation or for improvement of skeletal muscles during two weeks and had not undergone arthrocentesis within four months prior to the blood tests such as CRP, CK-MM and AldoA evaluated at the baseline and at the end of the topical phytotherapy treatment of 6-week.

\section{Biochemical parameters}

In this study, the biochemical parameters such as CRP, CK$\mathrm{MM}$ and Aldo A were measured at the baseline and after 6-week of phytotherapy treatment from the serum of all participants. Each test for every patient has been rechecked by the S-240 Mindray fully automated biochemistry analyzer before reporting the final test result at the baseline and at the end of six weeks of treatment. Table 5 shows the results which indicated decreasing levels of CRP, CK-MM and Aldo A when compared with the levels at the baseline with the levels at the end of six weeks of treatment considering 174 females and 87 males separately or together and that these differences were highly significant $(\mathrm{P}<0.0001)$ for all the parameters either together or separately by gender. Percentage of improvements after the end of six weeks of treatment for all the biomarkers such as CRP, CK-MM and AldoA were highly significant $(\mathrm{p}<0.0001)$ in case of combined-sex, female-only and male-only, which were shown in Figure 2.

\section{The high and low ranges of biochemical parameters and their percentage of improvements}

The reference ranges of the three biomarkers are: $\mathrm{CRP}<6 \mathrm{mg} / \mathrm{L}$, $\mathrm{CK}-\mathrm{MM}<168 \mathrm{U} / \mathrm{L}$ and AldoA<7.6 U/L. All the participants were divided into six categories according to the high and low ranges of the three biomarkers: $\mathrm{CRP}<6 \mathrm{mg} / \mathrm{L}$ and CRP $>6 \mathrm{mg} / \mathrm{L}$; CK-MM $<168$ $\mathrm{U} / \mathrm{L}$ and CK-MM>168 U/L; and AldoA<7.6U/L and AldoA>7.6 U/L. The number of patients and their percentage of six categories for combined-sex, female-only and male-only are shown in Table 6.

Table 7 shows that the three biomarkers of all the six categories of patients based on high and low ranges were highly statistically significant $(\mathrm{p}<0.0001)$ both overall and separately by gender, when compared the baseline with the results at the end of six weeks of treatment. 
Citation: Ganguly A, Ganguly D, Banerjee SK. Topical Phytotherapeutic Treatment: Management of Normalization of Elevated Levels of Biochemical Parameter During Osteoarthritic Disorders: A prospective Study. J Orthopedics Rheumatol. 2018; 5(1): 14

ISSN: $2334-2846$

Table 5: Statistical analysis of CRP, CK-MM and Aldolase A of 261 patients.

\begin{tabular}{|c|c|c|c|c|c|c|c|}
\hline \multirow{3}{*}{$\begin{array}{l}\text { Biochemical } \\
\text { parameter }\end{array}$} & \multirow{3}{*}{ Gender } & \multirow{3}{*}{$\begin{array}{c}\text { Baseline } \\
\text { Mean (SEM) }\end{array}$} & \multirow{3}{*}{$\begin{array}{l}\text { End of 6-week } \\
\text { Mean (SEM) }\end{array}$} & \multicolumn{4}{|c|}{$\begin{array}{l}\text { Improvements on elevated levels of biomarkers at the end of } \\
\qquad 6 \text {-week }\end{array}$} \\
\hline & & & & \multirow{2}{*}{ MD } & \multicolumn{2}{|c|}{$95 \% \mathrm{Cl}$ of difference } & \multirow{2}{*}{ p-value } \\
\hline & & & & & Lower limit & Upper limit & \\
\hline \multirow{3}{*}{ 号 } & Combined $(n=261)$ & $7.25(0.202)$ & $4.06(0.047)$ & 3.19 & 2.78 & 3.59 & $<0.0001$ \\
\hline & Female $(n=174)$ & $7.58(0.261)$ & $4.18(0.055)$ & 3.4 & 2.87 & 3.92 & $<0.0001$ \\
\hline & Male $(n=87)$ & $6.60(0.296)$ & $3.80(0.081)$ & 2.8 & 2.19 & 3.4 & $<0.0001$ \\
\hline \multirow{3}{*}{ 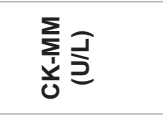 } & Combined $(n=261)$ & $187.85(6.548)$ & $97.94(1.729)$ & 89.91 & 76.6 & 103.21 & $<0.0001$ \\
\hline & Female $(n=174)$ & $168.72(7.213)$ & $91.59(2.007)$ & 77.13 & 62.4 & 91.86 & $<0.0001$ \\
\hline & Male $(n=87)$ & $226.10(12.411)$ & $110.70(2.842)$ & 115.4 & 90.27 & 140.53 & $<0.0001$ \\
\hline \multirow{3}{*}{$\begin{array}{l}\varangle \\
\frac{0}{0}\end{array}$} & Combined $(n=261)$ & $8.24(0.176)$ & $5.11(0.068)$ & 3.13 & 2.76 & 3.5 & $<0.0001$ \\
\hline & Female $(n=174)$ & $7.96(0.234)$ & $5.13(0.086)$ & 2.83 & 2.34 & 3.2 & $<0.0001$ \\
\hline & Male $(n=87)$ & $8.80(0.237)$ & $5.10(0.113)$ & 3.7 & 3.18 & 4.22 & $<0.0001$ \\
\hline
\end{tabular}

Table 6: Baseline allocation of number of patients to high and low ranges of three biochemical markers and their percentage.



Figure $4 \mathrm{~A}$ shows the graphical representation of high and low ranges of CRP, CK-MM and Aldo A levels of 261 combined-sex subjects. The percentage of improvements in their high and low ranges of six categories including $\mathrm{CRP}<6.0 \mathrm{mg} / \mathrm{L}, \mathrm{CRP}>6.0 \mathrm{mg} / \mathrm{L}$, CK-MM $<168.0$ U/L, CK-MM $>168.0$ U/L, AldoA<7.6 U/L and AldoA>7.6 U/L after the end of treatment of six weeks were highly significant levels $(\mathrm{p}<0.0001)$.
Figure $4 \mathrm{~B}$ indicates the graphical representation of high and low ranges of CRP, CK-MM and AldoA levels of 174 female-only subjects. The percentage of improvements in their high and low ranges of six categories including $\mathrm{CRP}<6.0 \mathrm{mg} / \mathrm{L}, \mathrm{CRP}>6.0 \mathrm{mg} / \mathrm{L}, \mathrm{CK}-\mathrm{MM}<168.0$ $\mathrm{U} / \mathrm{L}, \mathrm{CK}-\mathrm{MM}>168.0 \mathrm{U} / \mathrm{L}$, AldoA<7.6 U/L and AldoA>7.6 U/L after the end of treatment of six weeks were highly significant levels $(\mathrm{p}<0.0001)$. 
Citation: Ganguly A, Ganguly D, Banerjee SK. Topical Phytotherapeutic Treatment: Management of Normalization of Elevated Levels of Biochemical Parameter During Osteoarthritic Disorders: A prospective Study. J Orthopedics Rheumatol. 2018; 5(1): 14

\section{ISSN: 2334-2846}

Table 7: Analysis of mean, standard error of the mean, mean difference and $95 \%$ confidence interval of 261 patients with CRP $<6$ and $>6$ mg/L,CK-MM $<168$ and $>168$ $\mathrm{U} / \mathrm{L}$ and Aldolase $\mathrm{A}<7.6$ and $>7.6 \mathrm{U} / \mathrm{L}$

\begin{tabular}{|c|c|c|c|c|c|c|c|c|c|c|c|c|c|c|c|c|c|c|c|}
\hline \multirow{4}{*}{ 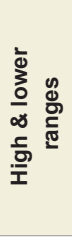 } & \multirow{4}{*}{ Gender } & \multicolumn{3}{|c|}{ aseline } & \multicolumn{3}{|c|}{$\begin{array}{c}\text { At the end of 6-week } \\
\text { treatment }\end{array}$} & \multicolumn{12}{|c|}{ Improvements on the elevated level of biomarkers at the end of 6-week treatment } \\
\hline & & \multirow{3}{*}{$\begin{array}{l}\text { CRP } \\
\text { Mean } \\
\text { (SEM) }\end{array}$} & \multirow{3}{*}{$\begin{array}{l}\text { CK-MM } \\
\text { Mean } \\
\text { (SEM) }\end{array}$} & \multirow{3}{*}{\begin{tabular}{|c}
$\begin{array}{c}\text { Aldolase } \\
\text { A }\end{array}$ \\
Mean \\
(SEM)
\end{tabular}} & \multirow{3}{*}{$\begin{array}{l}\text { CRP } \\
\text { Mean } \\
\text { (SEM) }\end{array}$} & \multirow{3}{*}{\begin{tabular}{|l|} 
CK-MM \\
$\begin{array}{l}\text { Mean } \\
\text { (SEM) }\end{array}$ \\
\end{tabular}} & \multirow{3}{*}{$\begin{array}{c}\begin{array}{c}\text { Aldolase } \\
\text { A }\end{array} \\
\text { Mean } \\
\text { (SEM) }\end{array}$} & \multicolumn{4}{|c|}{ CRP } & \multicolumn{4}{|c|}{ CK-MM } & \multicolumn{4}{|c|}{ Aldolase A } \\
\hline & & & & & & & & \multirow[b]{2}{*}{ MD } & \multicolumn{2}{|c|}{$95 \% \mathrm{Cl}$} & \multirow[b]{2}{*}{ p-value } & \multirow[b]{2}{*}{ MD } & \multicolumn{2}{|c|}{$95 \% \mathrm{Cl}$} & \multirow[b]{2}{*}{ p-value } & \multirow[b]{2}{*}{ MD } & \multicolumn{2}{|c|}{$95 \% \mathrm{Cl}$} & \multirow[b]{2}{*}{ p-value } \\
\hline & & & & & & & & & $\begin{array}{l}\text { Lower } \\
\text { limit }\end{array}$ & $\begin{array}{l}\text { Upper } \\
\text { limit }\end{array}$ & & & $\begin{array}{l}\text { Lower } \\
\text { limit }\end{array}$ & $\begin{array}{l}\text { Upper } \\
\text { limit }\end{array}$ & & & $\begin{array}{l}\text { Lower } \\
\text { limit }\end{array}$ & $\begin{array}{l}\text { Upper } \\
\text { limit }\end{array}$ & \\
\hline \multirow{3}{*}{$\begin{array}{l}0 \\
\text { v } \\
\frac{0}{0} \\
\frac{\alpha}{v}\end{array}$} & $\begin{array}{c}\text { Combined } \\
(n=91)\end{array}$ & $\begin{array}{c}4.55 \\
(0.083)\end{array}$ & $\begin{array}{r}240 . \\
(11.47\end{array}$ & $\begin{array}{l}9.43 \\
(0.290)\end{array}$ & $\begin{array}{c}3.75 \\
(0.067)\end{array}$ & $\begin{array}{l}103.93 \\
(2.654)\end{array}$ & $\begin{array}{c}5.17 \\
(0.116)\end{array}$ & 0.80 & 0.59 & 1.01 & $<0.0001$ & 136.53 & 113.28 & 159.77 & $<0.0001$ & 4.26 & 3.64 & 4.88 & 0.0001 \\
\hline & $\begin{array}{l}\text { Female } \\
(n=45)\end{array}$ & $\begin{array}{c}4.34 \\
(0.101)\end{array}$ & $\begin{array}{c}235.83 \\
(15.741)\end{array}$ & $\begin{array}{c}9.29 \\
(0.498)\end{array}$ & $\begin{array}{c}3.84 \\
(0.086)\end{array}$ & $\begin{array}{c}95.75 \\
(3.881)\end{array}$ & $\begin{array}{c}5.36 \\
(0.173) \\
\end{array}$ & 0.50 & 0.23 & 0.76 & 0.0001 & 140.08 & 107.85 & 72.3 & $<0.0001$ & 3.93 & 2.88 & 4.98 & 0.0001 \\
\hline & $\begin{array}{c}\text { Male } \\
(n=46)\end{array}$ & \begin{tabular}{|c|}
4.76 \\
$(0.124)$ \\
\end{tabular} & $\begin{array}{c}244.99 \\
(16.829)\end{array}$ & $\begin{array}{c}9.56 \\
(0.307) \\
\end{array}$ & $\begin{array}{c}3.66 \\
(0.100)\end{array}$ & $\begin{array}{l}33 \\
58)\end{array}$ & $\begin{array}{c}4.95 \\
(0.152) \\
\end{array}$ & 1.10 & 0.78 & 1.42 & $<0.0001$ & 133.06 & 9.00 & 167.11 & $<0.0001$ & 4.58 & 3.9 & 5.26 & $<0.0001$ \\
\hline \multirow[b]{2}{*}{ 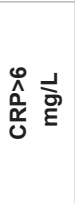 } & $\begin{array}{c}\text { Combined } \\
(\mathrm{n}=170)\end{array}$ & $\begin{array}{c}8.69 \\
(0.242)\end{array}$ & $\begin{array}{l}159.69 \\
(7.088)\end{array}$ & $\begin{array}{l}7.61 \\
(0.206)\end{array}$ & $\begin{array}{c}4.23 \\
(0.059)\end{array}$ & $\begin{array}{l}94 \\
(2.2\end{array}$ & $\begin{array}{r}5.0 \\
(0.08\end{array}$ & 4.46 & 3.97 & 4.95 & 0.0001 & 64.95 & 50.35 & 79.55 & $<0.0001$ & 2.54 & 2.1 & 2.98 & $<0.0001$ \\
\hline & $\begin{array}{l}\text { Female } \\
(n=129)\end{array}$ & $\begin{array}{c}8.70 \\
(0.291)\end{array}$ & $\begin{array}{l}145.30 \\
(6.969)\end{array}$ & $\begin{array}{c}7.49 \\
(0.252)\end{array}$ & $\begin{array}{c}4.30 \\
(0.065)\end{array}$ & $\begin{array}{c}90 . \\
(2.3\end{array}$ & $\begin{array}{c}5.05 \\
(0.098)\end{array}$ & 4.40 & 3.81 & 4.99 & $<0.0001$ & 55.17 & 40.69 & 69.65 & $<0.0001$ & 1.84 & 1.31 & 2.37 & $<0.0001$ \\
\hline \multirow{3}{*}{ 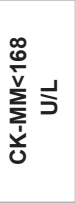 } & $\begin{array}{c}\text { Combined } \\
(n=112)\end{array}$ & $\begin{array}{c}8.27 \\
(0.083) \\
\end{array}$ & 196) & $\begin{array}{c}7.40 \\
(0.267)\end{array}$ & $\begin{array}{c}4.31 \\
(0.071) \\
\end{array}$ & $\begin{array}{c}84.60 \\
(2.161)\end{array}$ & $\begin{array}{c}4.90 \\
(0.102)\end{array}$ & 3.96 & 3.74 & 4.17 & $<0.0001$ & 22.68 & 15.08 & 30.28 & $<0.0001$ & 2.5 & 1.93 & 3.06 & 0.0001 \\
\hline & $\begin{array}{l}\text { Female } \\
(n=97)\end{array}$ & $\begin{array}{c}8.20 \\
(0.000)\end{array}$ & 474) & $\begin{array}{c}7.28 \\
(0.283)\end{array}$ & $\begin{array}{c}4.35 \\
(0.075) \\
\end{array}$ & $\begin{array}{l}84 . \\
(2.3\end{array}$ & $\begin{array}{c}4.90 \\
(0.110) \\
\end{array}$ & 3.85 & 3.70 & 4.00 & 0.0001 & 23.3 & 5.04 & 1.55 & $<0.0001$ & 2.38 & 1.78 & 2.98 & 0.0001 \\
\hline & $\begin{array}{c}\text { Male } \\
(n=15)\end{array}$ & $\begin{array}{c}8.70 \\
(0.630)\end{array}$ & 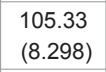 & $\begin{array}{c}8.21 \\
(0.798)\end{array}$ & $\begin{array}{c}4.10 \\
(0.204)\end{array}$ & $\begin{array}{l}86 \\
(5 .\end{array}$ & $\begin{array}{r}4.5 \\
(0.2\end{array}$ & 60 & 3.24 & 96 & 0.0001 & 8.72 & 2.12 & 9.56 & $<0.0001$ & 3.29 & .55 & 5.03 & 0.0001 \\
\hline \multirow{3}{*}{ 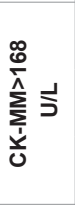 } & $\begin{array}{c}\text { Combined } \\
(n=149)\end{array}$ & $\begin{array}{c}6.00 \\
(0.202)\end{array}$ & 271) & $\begin{array}{l}8.87 \\
(0.221)\end{array}$ & $\begin{array}{c}3.87 \\
(0.058)\end{array}$ & $\begin{array}{l}107.48 \\
(2.330)\end{array}$ & $\begin{array}{c}5.26 \\
(0.090)\end{array}$ & 13 & 1.71 & 2.54 & 0.0001 & 140.94 & 124.03 & 157.85 & $<0.0001$ & 3.61 & 3.14 & 4.08 & 0.0001 \\
\hline & $\begin{array}{l}\text { Female } \\
(n=77)\end{array}$ & $\begin{array}{c}5.86 \\
(0.260)\end{array}$ & $\begin{array}{c}245.74 \\
(10.413)\end{array}$ & $\begin{array}{l}8.81 \\
(0.370)\end{array}$ & $\begin{array}{c}3.97 \\
(0.075)\end{array}$ & $\begin{array}{c}99.82 \\
(3.401)\end{array}$ & $\begin{array}{c}5.42 \\
(0.129)\end{array}$ & 1.89 & 1.35 & 2.42 & $=0.0001$ & 145.92 & 124.28 & 167.56 & $<0.0001$ & 3.39 & 2.61 & 4.16 & $<0.0001$ \\
\hline & $\begin{array}{c}\text { Male } \\
(n=72)\end{array}$ & $\begin{array}{c}6.15 \\
(0.310)\end{array}$ & $\begin{array}{c}251.29 \\
(13.068)\end{array}$ & $\begin{array}{c}8.94 \\
(0.233)\end{array}$ & $\begin{array}{c}3.77 \\
(0.088)\end{array}$ & $\begin{array}{l}115.67 \\
(2.888)\end{array}$ & $\begin{array}{c}5.09 \\
(0.123) \\
\end{array}$ & 2.38 & 1.74 & 3.02 & $<0.0001$ & 135.62 & 109.16 & 162.08 & $<0.0001$ & 3.85 & 3.33 & 4.37 & $<0.0001$ \\
\hline \multirow{2}{*}{$\begin{array}{l}\frac{0}{1} \\
\text { v } \\
\frac{0}{0} \\
\frac{0}{\alpha}\end{array}$} & $\begin{array}{c}\text { Combined } \\
(\mathrm{n}=100)\end{array}$ & $\begin{array}{c}8.78 \\
(0.364)\end{array}$ & 0 & $\begin{array}{l}5.76 \\
(0.103)\end{array}$ & $\begin{array}{c}4.28 \\
(0.069)\end{array}$ & $\begin{array}{l}96.06 \\
(2.970)\end{array}$ & $\begin{array}{c}4.84 \\
(0.104)\end{array}$ & 4.50 & 3.77 & 5.23 & $<0.0001$ & 54.84 & 37.02 & 72.66 & $<0.0001$ & 0.92 & 0.63 & 1.04 & $<0.0001$ \\
\hline & $\begin{array}{l}\text { Female } \\
(n=79)\end{array}$ & $\begin{array}{c}8.64 \\
(0.418)\end{array}$ & $\begin{array}{l}135.84 \\
(6.944)\end{array}$ & $\begin{array}{l}5.62 \\
(0.117)\end{array}$ & $\begin{array}{c}4.36 \\
(0.073)\end{array}$ & $\begin{array}{l}91.66 \\
(3.178)\end{array}$ & $\begin{array}{c}4.74 \\
(0.110)\end{array}$ & 4.28 & 3.44 & 5.12 & $<0.0001$ & 44.18 & 29.09 & 59.26 & $<0.0001$ & 0.88 & 0.56 & 1.2 & $<0.0001$ \\
\hline & $\begin{array}{c}\text { Combined } \\
(\mathrm{n}=161)\end{array}$ & $\begin{array}{c}6.29 \\
(0.204)\end{array}$ & $\begin{array}{l}210.80 \\
(8.698)\end{array}$ & $\begin{array}{l}9.78 \\
(0.198)\end{array}$ & $\begin{array}{c}3.93 \\
(0.061)\end{array}$ & $\begin{array}{l}99.12 \\
(2.111)\end{array}$ & $\begin{array}{c}5.27 \\
(0.087)\end{array}$ & 2.36 & 1.94 & 2.78 & $<0.0001$ & 111.68 & 94.07 & 129.29 & $<0.0001$ & 4.51 & 4.08 & 4.93 & $<0.0001$ \\
\hline & $\begin{array}{l}\text { Female } \\
(n=95)\end{array}$ & $\begin{array}{c}6.69 \\
(0.301) \\
\end{array}$ & $\begin{array}{c}196.06 \\
(11.163)\end{array}$ & $\begin{array}{c}9.90 \\
(0.294)\end{array}$ & $\begin{array}{c}4.03 \\
(0.078) \\
\end{array}$ & $\begin{array}{l}91.52 \\
(2.570)\end{array}$ & \begin{tabular}{|c|}
5.45 \\
$(0.118)$ \\
\end{tabular} & 2.66 & 2.05 & 3.27 & $<0.0001$ & 104.54 & 81.94 & 127.14 & $<0.0001$ & 4.45 & 3.82 & 5.07 & $<0.0001$ \\
\hline & $\begin{array}{c}\text { Male } \\
(n=66)\end{array}$ & $\begin{array}{c}5.73 \\
(0.230)\end{array}$ & $\begin{array}{c}232.02 \\
(13.686)\end{array}$ & $\begin{array}{c}9.61 \\
(0.231)\end{array}$ & $\begin{array}{c}3.77 \\
(0.093)\end{array}$ & $\begin{array}{l}110.04 \\
(3.149)\end{array}$ & $\begin{array}{c}5.02 \\
(0.124)\end{array}$ & 1.96 & 1.47 & 2.45 & $<0.0001$ & 121.98 & 94.19 & 149.76 & $<0.0001$ & 4.59 & 4.07 & 5.11 & $<0.0001$ \\
\hline
\end{tabular}

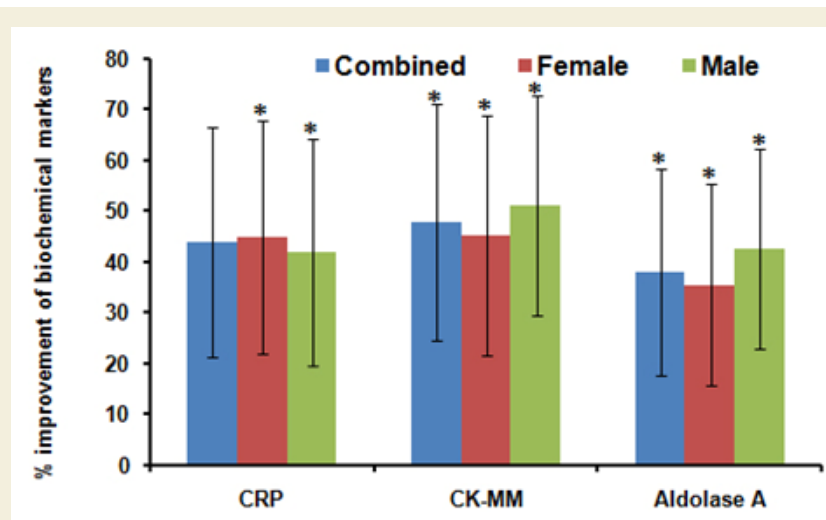

Figure 3: Graphical representation of overall \% of improvement of C-reactive protein (CRP), Creatine kinase-muscle (CK-MM) and Aldolase A (AldoA) levels of combined-sex $(n=261)$, female only $(n=174)$ and male only $(n=87)$ $\left({ }^{*} p<0.0001\right)$.
Figure 4C shows the graphical representation of high and low ranges of CRP, CK-MM and Aldo A levels of 87 male-only subjects. The percentage of improvements in their high and low ranges of six categories including $\mathrm{CRP}<6.0 \mathrm{mg} / \mathrm{L}, \mathrm{CRP}>6.0 \mathrm{mg} / \mathrm{L}, \mathrm{CK}-\mathrm{MM}<168.0$ $\mathrm{U} / \mathrm{L}, \quad \mathrm{CK}-\mathrm{MM}>168.0 \mathrm{U} / \mathrm{L}$, AldoA<7.6 U/L and AldoA>7.6 U/L after the end of treatment of six weeks were highly significant levels $(\mathrm{p}<0.0001)$.

\section{Pearson's correlation coefficient}

All the Pearson's correlation coefficients among two biochemical markers were weak but highly significant $(\mathrm{p}<0.05)$ : CRP at the baseline $\left(\mathrm{CRP}^{\mathrm{b}}\right)$ and $\mathrm{CK}-\mathrm{MM}$ after the treatment $\left(\mathrm{CK}-\mathrm{MM}^{\mathrm{t}}\right)$ was $\mathrm{r}=-$ $0.123(\mathrm{p}=0.018)$ and shown in Figure 5A; CRP at the baseline $\left(\mathrm{CRP}^{\mathrm{b}}\right)$ and Aldo A after the treatment (Aldo $\left.A^{t}\right)$ was $r=-0.051(p=0.034)$ and shown in Figure $5 \mathrm{~B}$; CK-MM at the baseline $\left(\mathrm{CK}-\mathrm{MM}^{\mathrm{b}}\right)$ and Aldo A after the treatment $\left(\right.$ Aldo $\left.^{t}\right)$ was $r=0.215(p=0.000)$ and shown in Figure $5 \mathrm{C}$; $\mathrm{CRP}$ at the baseline $\left(\mathrm{CRP}^{\mathrm{b}}\right)$ and $\mathrm{CRP}$ after the treatment 
Citation: Ganguly A, Ganguly D, Banerjee SK. Topical Phytotherapeutic Treatment: Management of Normalization of Elevated Levels of Biochemical Parameter During Osteoarthritic Disorders: A prospective Study. J Orthopedics Rheumatol. 2018; 5(1): 14

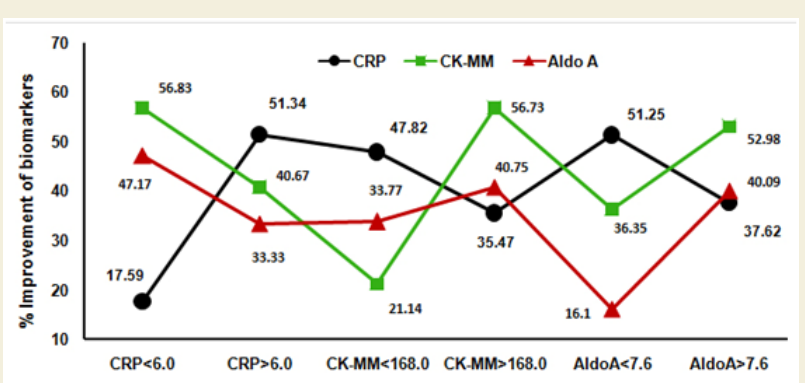

Figure 4A: Graphical representation of the high and low ranges of $C$-reactive protein (CRP), Creatine kinase-muscle (CK-MM) and Aldolase A (AldoA) levels of 261 combined-sex patients and their percentage of improvements (in all cases $\mathrm{p}<0.0001$ )

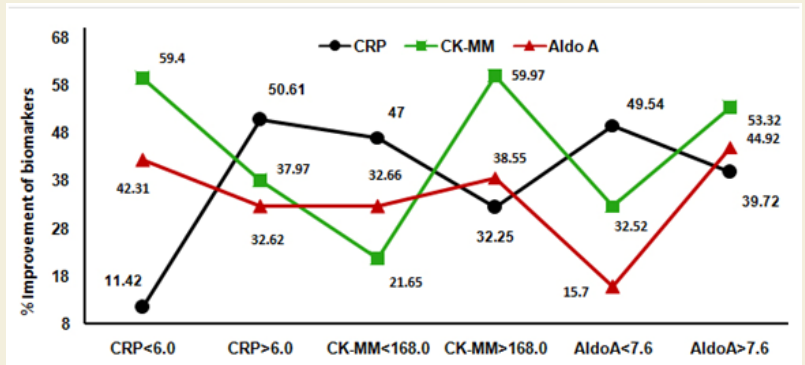

Figure 4B: Graphical representation of the high and low ranges of $\mathrm{C}$-reactive protein (CRP), Creatine kinase-muscle (CK-MM) and Aldolase A (AldoA) levels of 174 female-only patients and their percentage of improvements (in all cases $p<0.0001)$.

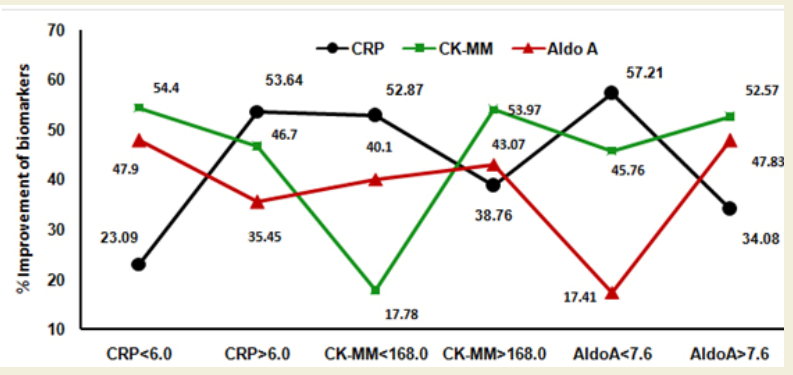

Figure 4C: Graphical representation of the high and low ranges of $\mathrm{C}$-reactive protein (CRP), Creatine kinase-muscle (CK-MM) and Aldolase A (AldoA) levels of 87 male-only patients and their percentage of improvements (in all cases $p<0.0001$ ).

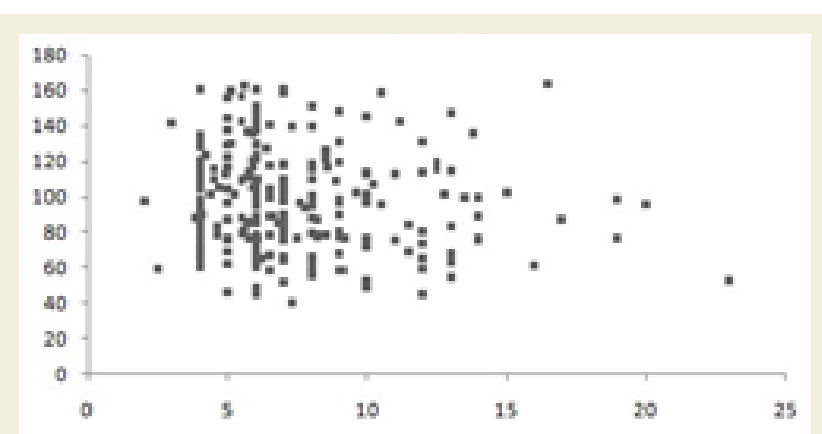

Figure 5A: Pearson's correlation coefficient between CRP at the baseline $\left(\mathrm{CRP}^{\mathrm{b}}\right)$ and the CK-MM after the treatment $\left(\mathrm{CK}-\mathrm{MM}^{\mathrm{t}}\right)[\mathrm{r}=-0.123$ and $\mathrm{p}=0.018]$.

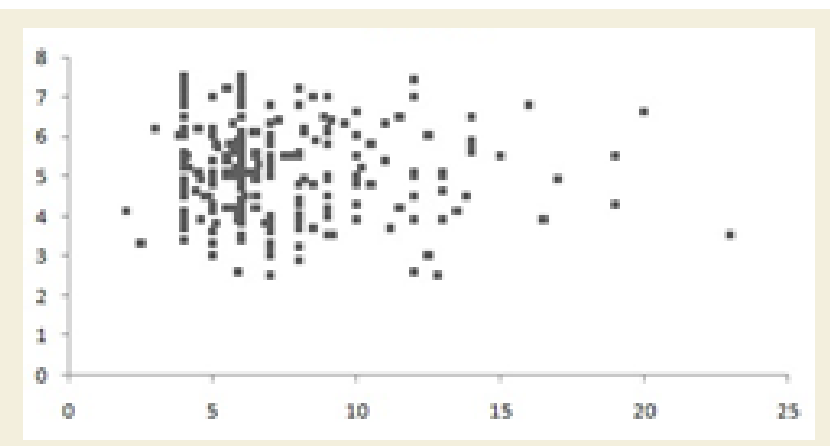

Figure 5B: Pearson's correlation coefficient between CRP at the baseline $\left(\mathrm{CRP}^{\mathrm{b}}\right)$ and $\mathrm{AldoA}$ after the treatment $\left(\mathrm{Aldo}^{t}\right)[\mathrm{r}=-0.051$ and $\mathrm{p}=0.034]$.

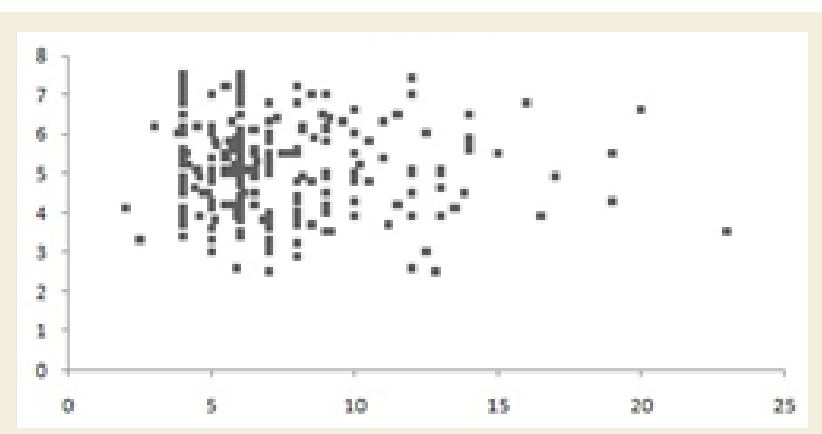

Figure 5C: Pearson's correlation coefficient between CK-MM at the baseline $\left(\mathrm{CK}-\mathrm{MM}^{\mathrm{b}}\right)$ and AldoA after the treatment $\left(\right.$ AldoA $\left.^{t}\right)[r=0.215$ and $p=0.000]$.

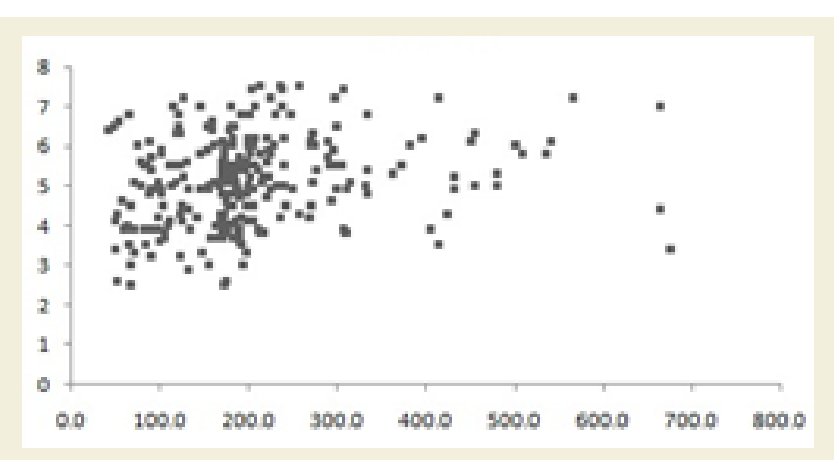

Figure 5D: Pearson's correlation coefficient between CRP at the baseline $\left(C R P^{b}\right)$ and $C R P$ after the treatment $(C R P t)[r=0.243$ and $p=0.000]$.

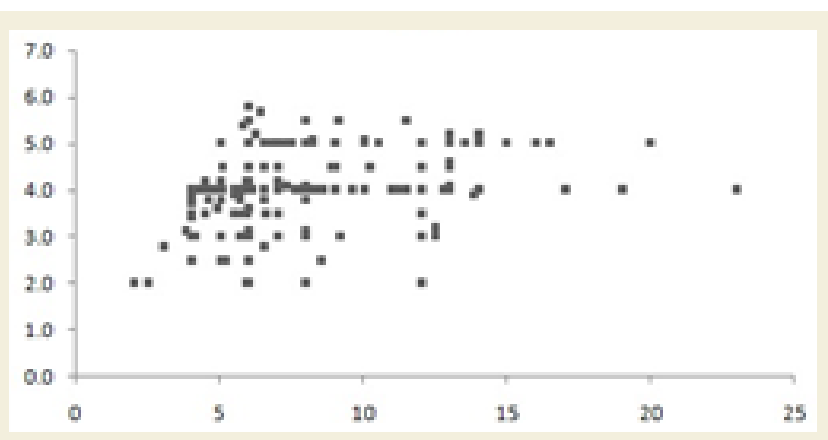

Figure 5E: Pearson's correlation coefficient between CRP at the baseline $\left(C^{b}\right)$ and $C R P$ after the treatment $\left(C R P^{t}\right)[r=0.243$ and $p=0.000]$. 
Citation: Ganguly A, Ganguly D, Banerjee SK. Topical Phytotherapeutic Treatment: Management of Normalization of Elevated Levels of Biochemical Parameter During Osteoarthritic Disorders: A prospective Study. J Orthopedics Rheumatol. 2018; 5(1): 14

$\left(\mathrm{CRP}^{\mathrm{t}}\right)$ was $\mathrm{r}=0.243(\mathrm{p}=0.000)$ and shown in Figure 5D; CK-MM at the baseline $\left(\mathrm{CK}-\mathrm{MM}^{\mathrm{b}}\right)$ and $\mathrm{CK}-\mathrm{MM}$ after the treatment (CK$\left.\mathrm{MM}^{\mathrm{t}}\right)$ was $\mathrm{r}=0.289(\mathrm{p}=0.000)$ and shown in Figure 5E and Aldo A at the baseline $\left(\operatorname{Aldo}^{\mathrm{b}}\right)$ and AldoA after the treatment $\left(\operatorname{AldoA}^{t}\right)$ was $r=0.234(p=0.000)$ and shown in Figure 5F.

\section{KOOS knee survey}

The improvements of the five separately scored subscales under KOOS knee survey after the end of six weeks of treatment were highly significant $(\mathrm{p}<0.0001)$ and shown in Figure 6A.

Percentage of improvement of pain, stiffness and daily functional activities under other three International approved scales and reduction of body weight

The percentage of improvements of pain, stiffness and daily functional performances under VAS, WOMAC Index and KPS were highly statistically significant $(\mathrm{p}<0.0001)$ both over all and separately by gender and shown in Figures 6B-6D.

\section{Reduction of body weight}

Figure 7 shows the percentage of reduction of body weights of combined-sex, female-only and male-only patients after the end of six-week treatment protocol as assessed by BMI were highly statistically significant $(\mathrm{p}<0.0001)$.

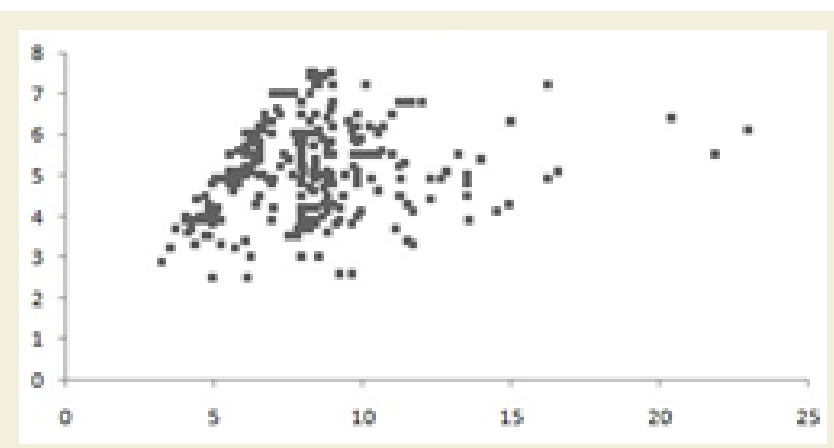

Figure 5E: Pearson's correlation coefficient between AldoA at the baseline $\left(A_{1 d o} A^{b}\right)$ and Aldo $A$ after the treatment (Aldo $\left.A^{t}\right)[r=0.234$ and $p=0.000]$.

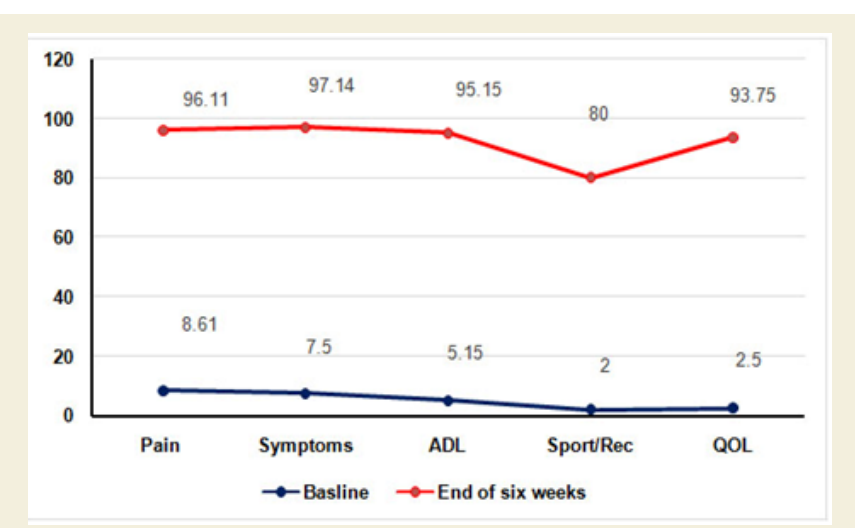

Figure 6A: KOOS profiles before and after the treatment of six weeks by phytotherapy. Mean KOOS score $(n=261)$ at the baseline and at the end of six weeks assessments $(p<0.001)$.
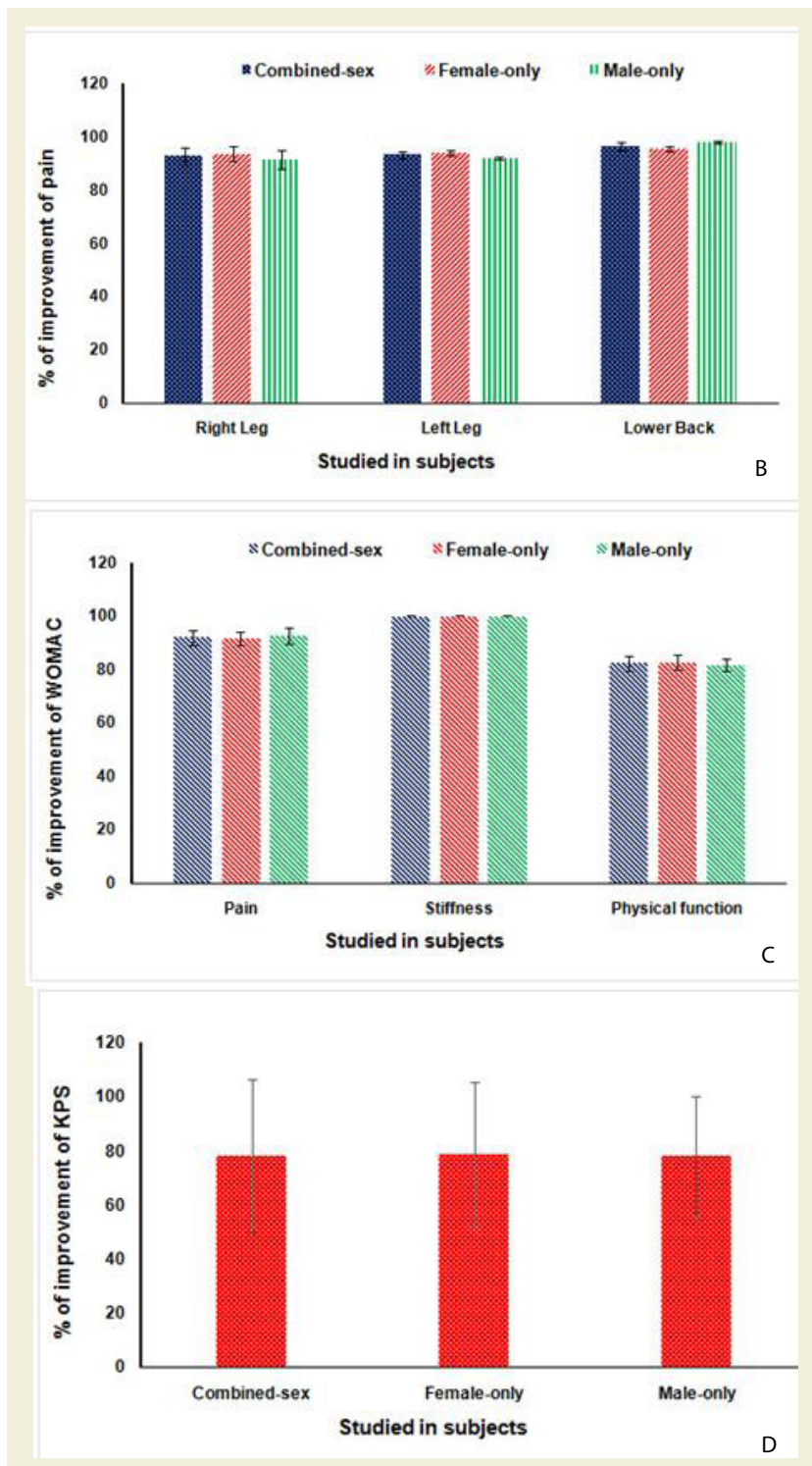

Figure 6B-C: \% of Improvement of pain under VAS after 6-week treatmen $(p<0.0001)$. C: $\%$ of Improvement of pain, stiffness and physical functional abilities under WOMAC osteoarthritis Index after 6-week treatment $(p<0.0001)$. D: \% of Improvement of daily functional performance under Karnofsky performance status scale (KPS) after 6-week treatment $(p<0.0001)$.

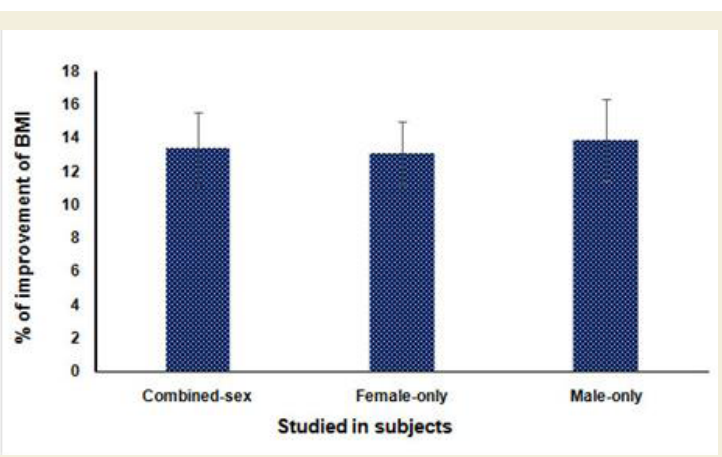

Figure 7: \% of Improvement of reduction of body weight assessed by body mass index $(B M I)$ after 6 -week treatment $(p<0.0001)$. 


\section{Improvement of $\mathrm{OAD}$ as per radiological images}

All the anterior-posterior (AP) X-ray reports of 261 patients with $\mathrm{OAD}$ at the baseline exhibited degenerative changes, particularly in the medial tibio-femoral compartment, with marked joint space narrowing and bilateral varus/valgus deformities. Some cases exhibited near-complete medial compartment joint space obliteration and also degenerative changes with osteophytes in the lumbar vertebrae. The AP knee X-rays and lumbar vertebrae of patients after six weeks of treatment indicated no such degenerative changes. X-rays images of two such patients suffering with pain in the knee joint and lumbar region before and after the treatment are depicted in Figures 7A-7B. Table 4 shows the improvement of the radiological images before and after the treatment under the K-L grading scale.

\section{Discussion}

In the present study, the importance of the risk factors for OAD i.e. elevated levels of certain biochemical parameters such as CRP, CK-MM and Aldo A in the serum of OAD patients has been taken care for diminishing their levels with the help of topical phytotherapy treatment. The reference value for each parameter in adults has been established as $<6 \mathrm{mg} / \mathrm{L}$ for CRP, $<168 \mathrm{U} / \mathrm{L}$ for CK-MM and $<7.6$ U/L for AldoA. CRP levels increase due to inflammation. CK-MM levels are elevated in response to muscular dystrophy, connective tissue damage, etc. and AldoA levels increase due to skeletal muscle damages and bone erosion, suggesting that these markers may be risk factors for OADs [18,19,21,22,26,65-68]. However, previous studies were conducted on the individual elevated level of biochemical marker either CRP or CK-MM or AldoA in separate subjects by several researchers $[20,24,27,72]$ but so far no study has attempted to correlate the risk factors, such as muscular damage, skeletal muscle damage and inflammation, with other diseases, such as OADs.

In recent era, plant derived phytochemicals are called phytomedicines. The biochemical mechanism of actions of these phytomedicines for osteoarthritis (OA) prevention is reported by several researchers [31-64,72]. Moreover, Dragos D et al. [54] documented that phytochemicals extracted from several plant species could be prevented the joint disorders with mechanism of their actions. The joint disorders are mainly related to osteoarthritis (OA), rheumatoid arthritis (RA) and finally leading to inflammation, muscular damage, skeletal muscle damage, bone degeneration etc. All of these above-mentioned diseases cause alteration of biochemical mechanisms of action such as enzymatic changes in blood, synovial fluid and in different cell types by different clinical, in vitro and in vivo studies [54].

In the present study, it was observed that three biochemical markers in serum resulted a significantly decreasing level when phytomedicines applied through aqueous phytoextracts of Cissus quadrangularis (whole plant), Calotropis gigantean (root and leaves), Zingiber officinalis (rhizome), Rosmarinus officinalis (leaves and flower), Boswellia serrata (resin), Curcuma longa (rhizome) and Withania somnifera (root) mixed with Sesamum indicum (seed oil) and beehive-wax (Table 3) [28-64]. The present study has an evidence that declining CRP, CK-MM and Aldo A levels after 6-week specialized topical treatment in combined-sex, female-only and male-only subjects due to decreasing activity of tumor necrosis factor-alpha (TNF- $\alpha$ ) while increasing activity of ant-inflammatory interleukins (specially IL-6 and IL-10) by these phytomedicines in the repair mechanisms process [31-64].

However, researchers have studied with single plant species and/ or two species in combinations for OA therapy but present study was done by using seven plant species and their different parts along with seed oil of one plant and beehive-wax and results shown may be synergistic effect on biochemical mode of action [31-64]. The topical phytotherapy in OADs majorly found in animal studies but present study can be an achievement to repair muscles and bones and also skeletal muscles of human by the assessment of normalization of biochemical markers such CRP, CK-MM and AldoA in OADs patients.

Form the present results, it is firmly confirmed that all the biochemical parameters such as CRP, CK-MM and Aldo A were diminished substantially with highly significant values $(\mathrm{p}<0.0001)$ in all cases and the percentage of improvements were also highly significant $(\mathrm{p}<0.0001)$ in each case after the 6-week of phytotherapy treatment (Table 5) (Figures 4A-4C). As shown in Tables 5 and 6 and Figures $4 \mathrm{~A}-4 \mathrm{C}$, the risk factors for muscular degeneration, skeletal muscle damage and inflammation are closely related. Furthermore, a continuous increasing trend was observed for all three biomarkers regardless of whether the ranges were lower or higher. However, the risk associated with CK-MM levels was substantially higher than that associated with the other two markers such as Aldo A and CRP in subjects with OADs (Figures 4A-4C).

It is further confirmed that the high and low ranges of all biomarkers such as CRP $(<6 \mathrm{mg} / \mathrm{L}$ and $>6 \mathrm{mg} / \mathrm{L})$, CK-MM $(<168$ $\mathrm{U} / \mathrm{L}$ and $>168 \mathrm{U} / \mathrm{L})$ and Aldo $\mathrm{A}(<7.6 \mathrm{U} / \mathrm{L}$ and $>7.6 \mathrm{U} / \mathrm{L})$ were diminished substantially for combined-sex, female-only and maleonly patients with highly significant values $(\mathrm{p}<0.0001)$ in all cases (Table 7 ) and their percentage of improvements were also highly significant $(\mathrm{p}<0.0001)$ in each case (Figures $4 \mathrm{~A}-4 \mathrm{C})$ after the 6-week of phytotherapy treatment. It is interesting to note that the number of patients and their percentage were not uniform so far as their high and low ranges of biochemical markers were concerned (Table 6).

As shown in Table 7 and Figures $4 \mathrm{~A}-4 \mathrm{C}$, the risk factors for muscular degeneration, skeletal muscle damage and inflammation are closely related. Furthermore, a continuous increasing trend was observed for all three biomarkers regardless of whether the ranges were lower or higher. However, the risk associated with CK-MM levels was substantially higher than that associated with the other two markers such as Aldo A and CRP in subjects with OADs. Moreover, the result shows the high predictive values of the three biomarkers in patients with OADs when the correlation coefficients (r-values) are separately calculated among the two biomarkers with highly significant values $(\mathrm{p}<0.05)$ in all cases (Figures $5 \mathrm{~A}-5 \mathrm{~F}$ ).

Besides biochemical markers, it has been emphasized several guidelines on different parameters such as pain, daily activities performance and quality of life under KOOS and K-L radiological grading scale of international Literature, the present study dealt with important guidelines as per the standard clinical outcomes for pain and related parameters such as VAS, WOMAC Index, KOOS, KPS and the K-L grading scale used for assessing the effect of novel 
Citation: Ganguly A, Ganguly D, Banerjee SK. Topical Phytotherapeutic Treatment: Management of Normalization of Elevated Levels of Biochemical Parameter During Osteoarthritic Disorders: A prospective Study. J Orthopedics Rheumatol. 2018; 5(1): 14

treatments on OADs by several researchers that pain parameters, functional disability, quality of life by knowing scoring methods and their decreasing data along with biochemical and imaging markers are evaluated along with normalization of elevated levels of the biochemical markers such as CRP, CK-MM, and AldoA by topical application of phytoconstituents correlated with pain scales and radiological gradation through images (Figures 3-7) [65-68].

The present study suggests that phytomedicines contain in phytoextracts have potential therapeutic impact on biochemical mechanism of action in the target cell(s) after topical application of above-mentioned phytomedicines. Moreover, the main aims of the treatment are to control pain, to maintain joint flexibility, to optimize joint and limb function and to improve quality of life, which are archived at the end of 6-week treatment supported by improved radiological features (Figures 2A-2B)

\section{Conclusion}

The present study with decreasing levels of biochemical parameters such as CRP, CK-MM and AldoA as a novel approach by the synergistic effect of phytomedicines contain in phytoextracts and can be an alternative of synthetic medicines to prevent OADs permanently. In general, OAD prevents only by using NSAIDs for pain relief or hyaluronic acid and corticosteroid injection for pain, stiffness and inflammation control temporarily and ultimately, total knee replacement (TKR) but these phytomedicines contain in phytoextracts may have ability to repair biochemically in the target cells permanently [32-62,70-72]. In recent research, phytotherapy indicated no need of revision of TKR [72]. Interestingly, as per international Literature, the present study revealed that pain parameters, functional disability, quality of life by using scoring methods and their decreasing data along with biochemical and imaging markers are firmly concluded that the elevated levels of the biochemical markers such as CRP, CK-MM, and AldoA represent the risks of inflammation, muscle degeneration, and skeletal muscle damage during $\mathrm{OAD}$, can be successfully normalized by topical application of phytoconstituents correlated with pain scales and radiological gradation through images (Figures 3-7). It is suggesting that in future study to know biochemical mechanisms in different cell types such as chondriocytes and osteocytes regeneration with the help of phytochemicals extracted from various Indian medicinal plants.

\section{References}

1. Felson DT (1988) Epidemiology of hip and knee osteoarthritis. Epidemiol Rev 10: $1-28$.

2. Bijlsma JW, Berenbaum F, Lafeber FP (2011) Osteoarthritis: an update with relevance for clinical practice. Lancet 377: 2115-2126.

3. Johnson VL, Hunter DJ (2014) The epidemiology of osteoarthritis. Best Pract Res Clin Rheumatol 28: 5-15.

4. Mabey T, Honsawek S (2015) Role of vitamin D in osteoarthritis: molecular, cellular, and clinical perspectives. Int J Endocrinol 2015: 383918.

5. Li H, Zeng C, Wei J, Yang T, Gao SG, et al. (2016) Serum calcium concentration is inversely associated with radiographic knee osteoarthritis: a cross-sectional study. Medicine (Baltimore) 95: e2838.

6. Cross M, Smith E, Hoy D, Nolte S, Ackerman I, et al. (2014) The global burden of hip and knee osteoarthritis: estimates from the global burden of disease 2010 study. Ann Rheum Dis 73: 1323-1330.

7. Ganguly A (2015) Degenerative changes in lumbar region always lead to bilateral degenerative changes in knee-joints and vice-versa: sensation of pain cannot only be the parameter of degeneration. Anat Physiol S4: 1-11.

8. Ganguly A (2015) Degenerative changes in lumbar-region occur simultaneously with bilateral-osteoarthritic changes in knee-joints and vice versa: normalization with topical application of phytoconstiuents by specialized techniques involving possible cartilage-regeneration. Int J Recent Sci Res 6: 6331-6346.

9. Ganguly A (2015) Obtaining normal flexion and extension of knee joints on supine, prone and standing positions in osteoarthritis by topical phytotherapeutic treatment irrespective of age and sex. Int J Phytomedicine 7: 290-301

10. Garnero P, Piperno M, Gineyts E, Christgau S, Delmas PD, et al. (2001) Cross sectional evaluation of biochemical markers of bone, cartilage, and synovial tissue metabolism in patients with knee osteoarthritis: relations with disease activity and joint damage. Ann Rheum Dis 60: 619-626.

11. Ganguly A (2014) Tropical phytotherapeutic treatment for achieving knee symmetry in osteoarthritis-a sustainable approach. Int J Phytomedicine 6: 489-509.

12. Otterness IG, Swindell AC, Zimmerer RO, Poole AR, Ionescu M, et al. (2000) An analysis of 14 molecular markers for monitoring osteoarthritis: segregation of the markers into clusters and distinguishing osteoarthritis at baseline. Osteoarthritis Cartil 8: 180-185.

13. Liu J, Shikhman AR, Lotz MK, Wong CH (2001) Hexosaminidase inhibitors as new drug candidates for the therapy of osteoarthritis. Chem Biol 8: 701-711.

14. Parsons S, Alesci S, Feuerstein G, Wang J (2008) Biomarkers in the development of novel disease-modifying therapies for osteoarthritis. Biomark Med 2: 587-602.

15. Kaysen GA (2009) Biochemistry and biomarkers of inflamed patients: why look, what to assess. Clin J Am Soc Nephrol 4 Suppl 1: S56-S63.

16. Dam EB, Loog M, Christiansen C, Byrjalsen I, Folkesson J, et al. (2009) Identification of progressors in osteoarthritis by combining biochemical and MRI-based markers. Arthritis Res Ther 11: R115.

17. Long F, Cai X, Luo W, Chen L, Li K (2014) Role of aldolase A in osteosarcoma progression and metastasis: in vitro and in vivo evidence. Oncol Rep 32: 2031-2037.

18. Spector TD, Hart DJ, Nandra D, Doyle DV, Mackillop N, et al.(1997) Low-level increases in serum C-reactive protein are present in early osteoarthritis of the knee and predict progressive disease. Arthritis Rheum 40: 723-727.

19. Smith JW, Martins TB, Gopez E, Johnson T, Hill HR, et al. (2012) Significance of C-reactive protein in osteoarthritis and total knee arthroplasty outcomes. Ther Adv Musculoskelet Dis 4: 315-325.

20. Zhang J (2018) Meta-analysis of serum C-reactive protein and cartilage oligomeric matrix protein levels as biomarkers for clinical knee osteoarthritis. BMC Musculoskelet Disord 19: 22

21. Laureys M, Sion JP, Slabbynck H, Steenssens L, Cobbaert C, et al. (1991) Macromolecular creatine kinase type 1: a serum marker associated with disease. Clin Chem 37: 430-434.

22. Galarraga B, Sinclair D, Fahie-Wilson MN, Mccrae FC, Hull RG, et al. (2003) A rare but important cause for a raised serum creatine kinase concentration: two case reports and a literature review. Rheumatology (Oxford) 42: 186-188.

23. Burtis CA, Ashwood AR, Burns DE (2012) Tietz text book of clinical chemistry and molecular diagnostic $\left(5^{\text {th }}\right.$ edn). Elsevier Saunders, USA, pp. 572-657.

24. Ganguly A (2018) Impact of topical phytotherapeutic effects on elevated level of serum creatine kinase-muscle as risk factor of muscular degeneration in knee-osteoarthritis: Part III. A systematic meta-analysis. Int Arch Bio Med Clin Res.

25. Ukaji F, Kitajima I, Kubo T, Shimizu C, Nakajima T, et al. (1999) Serum samples of patients with rheumatoid arthritis contain a specific autoantibody to "denatured" aldolase A in the osteoblast-like cell line, MG-63. Ann Rheum Dis 58: $169-174$.

26. Kim HJ, Lee YH, Kim CK (2007) Biomarkers of muscle and cartilage damage and inflammation during a $200 \mathrm{~km}$ run. Eurp J Appl Physio 99: 443-447. 
Citation: Ganguly A, Ganguly D, Banerjee SK. Topical Phytotherapeutic Treatment: Management of Normalization of Elevated Levels of Biochemical Parameter During Osteoarthritic Disorders: A prospective Study. J Orthopedics Rheumatol. 2018; 5(1): 14

ISSN: 2334-2846

27. Ganguly A (2018) Role of topical phytotherapy on the risk factor of elevated level of serum Aldolase-A in knee-osteoarthritis: Part II. A systematic metaanalysis. Int Arch Bio Med Clin Res.

28. Ganguly A (2016) Normalization of varus/valgus deformities in osteoarthritis by external application of phytoconstituents: confirmed with anatomical observations and biochemical profiles and radiological images. Anat Physio 6: 1-11.

29. Ganguly A (2017) Diagnosis, prevention \& phytotherapy for osteoarthritic disorders: pain diagnostic parameters and prevention of OADs. SPS Publishers, USA, pp. 1-84

30. Belcaro G, Dugall M, Luzzi R, Hosoi M, Ledda A, et al. (2018) Phytoproflex supplementary management of osteoarthrosis: a supplement registry. Minerva Med 109: 88-94.

31. Shah U (2011) Cissus quadrangularis L.: phytochemicals, traditional uses and pharmacological activities-a review. Int J Pharm Pharm Sci 3: 41-44.

32. Mishra G, Srivastava S, Nagori BP (2010) Pharmacological and therapeutic activity of Cissus quadrangularis: an overview. Int J PharmTech Res 2: 12981310 .

33. Srivastava AK, Srivastava P, Behera BR (2011) Pharmacognostical \& phytochemical investigation of Cissus quadrangularis Linn. stem. Int J Pharm Res Dev 3: 207-215.

34. Pluemjai T, Saifah E (1986) Constituents of Cissus quadrangularis Linn. Th J Pharm Sci 11: 205-209.

35. Rastogi RP, Mehrotra BN (1993) Compendium of medicinal plants. 2: 19701979.

36. Kinghorn AD (2005) Quality standards of Indian medical plants 2: 62.

37. Sharma PC, Yelne MB, Dennis TJ (2000) Database on medicinal plants used in ayurveda \& siddha (Volume 3). Central council for research in Ayurveda and Siddha, India, pp. 43-49.

38. Raj SJ, Joseph B (2011) Pharmacognostic and traditional properties of Cissus quadrancularis Linn-an overview. Int J Pharma Bio Sci 2: 131-139.

39. Madan CL, Nayar SL (1959) A pharmacognostical study of the stem of Cissus quadrangularis Linn. J Sci Ind Res 18: 253-255.

40. Shukla R, Pathak A, Kambuja S, Sachan S, Mishra A, et al. (2015) Pharmacognostical, phytochemical and pharmacological overview: Cissus quadrangularis Linn. Indian J Pharm Biol Res 3: 59-65.

41. Kori $\mathrm{P}$, Alawa $\mathrm{P}$ (2014) Antimicrobial activity and phytochemical analysis of Calotropis gigantea root, latex extract. IOSR J Pharm 4: 07-11.

42. William A, Shamaki BU, Sadiq AA, Abdullahi A (2015) Phytochemical and elemental constituents, acute toxicity (LD50) studies of aqueous leaf extract of Calotropis procera. World J Pharm Sci 3: 2321-3086.

43. Rathod NR, Raghuveer I, Chitme HR, Chandra R (2009) Free radical scavenging activity of Calotropis gigantea on streptozotocin-induced diabetic rats. Indian J Pharm Sci 71: 615-621.

44. Huang SH, Lee CH, Wang HM, Chang YW, Lin CY, et al. (2014 6-dehydrogingerdione restrains lipopolysaccharide-induced inflammatory responses in RAW 264.7 macrophages. J Agric Food Chem 62: 9171-9179.

45. van Breemen RB, Tao Y, Li W (2011) Cyclooxygenase-2 inhibitors in ginger (Zingiber officinale). Fitoterapia 82: 38-43.

46. Grzanna R. Lindmark L, Frondoza CG (2005) Ginger--an herbal medicinal product with broad anti-inflammatory actions. J Med Food 8: 125-132.

47. Ueda H, Ippoushi K, Takeuchi A (2010) Repeated oral administration of a squeezed ginger (Zingiber officinale) extract augmented the serum corticosterone level and had anti-inflammatory properties. Biosci Biotechnol Biochem 74: 2248-2252.

48. Naderi Z, Mozaffari-Khosravi H, Dehghan A, Nadjarzadeh A, Husein HF (2015) Effect of ginger powder supplementation on nitric oxide and C-reactive protein in elderly knee osteoarthritis patients: a 12-week doubleblind randomized placebo-controlled clinical trial. J Tradit Complement Med 6: 199-203.
49. Altman RD, Marcussen KC (2001) Effects of a ginger extract on knee pain in patients with osteoarthritis. Arthritis Rheum 44: 2531-2538.

50. Alipour Z, Asadizaker M, Fayazi S, Yegane N, Kochak M, et al. (2016) The effect of gingeron pain and satisfaction of patients with knee osteoarthritis. Jundishapur J Chronic Dis Care 6: e34798.

51. Lee HY, Park SH, Lee M, Kim HJ, Ryu SY, et al. (2012) 1-Dehydro-[10]gingerdione from ginger inhibits IKK 3 activity for NF-KB activation and suppresses NF-KB-regulated expression of inflammatory genes. $\mathrm{Br} \mathrm{J}$ Pharmacol 167: 128-140.

52. Begum A, Sandhya S, Shaffath Ali S, Vinod KR, Reddy S, et al. (2013) An indepth review on the medicinal flora Rosmarinus officinalis (Lamiaceae). Acta Sci Pol Technol Aliment 12: 61-73.

53. Sotelo-Felix JI, Martinez-Fong D, Muriel P, Santillán RL, Castillo D, et al. (2002) Evaluation of the effectiveness of Rosmarinus officinalis (Lamiaceae) in the alleviation of carbon tetrachloride-induced acute hepatotoxicity in the rat. J Ethnopharmacol 81: 145-154.

54. Dragos D, Gilca M, Gaman L, Vlad A, losif L, et al. (2017) Phytomedicine in joint disorders. Nutrients 9: E70.

55. Sharma A, Chhikara S, Ghodekar SN, Bhatia S, Kharya MD, et al. (2009) Phytochemical and Pharmacological investigations on Boswellia serrata. Pharmacogn Rev 3: 206-215.

56. Srivastav AK, Das P (2014) Phytochemical extraction and characterization of roots of Withania somnifera for its anti-bacterial, anti-oxidant, antiinflammation and analgesic activity. Int J Innov Res Dev 3: 22-33.

57. Hsu DZ, Chen SJ, Chu PY, Liu MY (2013) Therapeutic effects of sesame oi on monosodium urate crystal-induced acute inflammatory response in rats. Springerplus 2: 659 .

58. Sotnikova R, Ponist S, Navarova J, Mihalova D, Tomekova V, et al. (2009) Effects of sesame oil in the model of adjuvant arthritis. Neuro Endocrinol Lett 30 (Suppl 1): 22-24

59. Khadem Haghighian M, Alipoor B, Malek Mahdavi A, Eftekhar Sadat B Asghari Jafarabadi M, et al. (2015) Effects of sesame seed supplementation on inflammatory factors and oxidative stress biomarkers in patients with knee osteoarthritis. Acta Med Iran 53: 207-213.

60. Hemshekhar M, Thushara RM, Jnaneshwari S, Devaraja S, Kemparaju K, et al. (2013) Attenuation of adjuvant-induced arthritis by dietary sesamol via modulation of inflammatory mediators, extracellular matrix degrading enzymes and antioxidant status. Eur J Nutr 52: 1787-1799.

61. Carbajal D, Molina V, Valdes S, Arruzazabala ML, Más R, et al. (1998) Antiinflammatory activity of D-002: an active product isolated from beeswax. Prostaglandins Leukot Essent Fatty Acids 59: 235-238.

62. Ravelo Y, Molina V, Carbajal D, Fernández L, Fernández JC, et al. (2001) Evaluation of anti-inflammatory and antinociceptive effects of D-002 (beeswax alcohols). J Nat Med 65: 330-335.

63. Puente R, Illnait J, Mas R, Carbajal D, Mendoza S, et al. (2014) Evaluation of the effect of D-002, a mixture of beeswax alcohols, on osteoarthritis symptoms. Korean J Intern Med 29: 191-202.

64. Fratini F, Cilia G, Turchi B, Felicioli A (2016) Beeswax: a mini review of its antimicrobial activity and its application in medicine. Asian Pac J Trop Med 9: 839-843

65. Bodian CA, Freedman G, Hossain S, Eisenkraft JB, Beilin Y (2001) The visual analog scale for pain: clinical significance in postoperative patients. Anesthesiology 95: 1356-1361.

66. Bellamy N, Buchanan WW, Goldsmith CH, Campbell J, Stitt LW (1988) Validation study of WOMAC: a health status instrument for measuring clinically important patient relevant outcomes to antirheumatic drug therapy in patients with osteoarthritis of the hip or knee. J Rheumatol 15: 1833-1840.

67. Roos EM, Lohmander LS (2003) The Knee injury and Osteoarthritis Outcome Score (KOOS): from joint injury to osteoarthritis. Health Qual Life Outcomes 1: 64 .

68. Kellgren JH, Lawrence JS (1957) Radiological assessment of osteo-arthrosis Ann Rheum Dis 16: 494-502. 
Citation: Ganguly A, Ganguly D, Banerjee SK. Topical Phytotherapeutic Treatment: Management of Normalization of Elevated Levels of Biochemical Parameter During Osteoarthritic Disorders: A prospective Study. J Orthopedics Rheumatol. 2018; 5(1): 14

ISSN: $2334-2846$

69. illett WS, Francis T (1930) Serological reactions in pneumonia with a nonprotein somatic fraction of Pneumococcus. J Exp Med 52: 561-571.

70. Zeigenhagen G, Drahovshy D, KlinisheBedeutung des (1983) C-reactiven protein. Med Klin 78: 45-50.

71. Rifai N, Tracy RP, Ridker PM (1999) Clinical efficacy of an automated high sensitivity C-reactive protein assay. Clin Chem 45: 2136-2141.

72. Cabaniss CD (1990) Creatine kinase. In: Walker HK, Hall WD, Hurst JW (Eds) Clinical Methods: The History, Physical, and Laboratory Examinations ( $3^{\text {rd }}$ edn). Butterworth Publishers, Boston, USA.
73. Feissli S (1966) Quantitative determination of Aldolase. Klin Wschr 44: 390.

74. Askari A, Gholami T, NaghiZadeh MM, Farjam M, Kouhpayeh SA, et al. (2016) Hyaluronic acid compared with corticosteroid injections for the treatment of osteoarthritis of the knee: a randomized control trail. Springerplus 5: 442.

75. Raynauld JP, Martel-Pelletier J, Dorais M, Haraoui B, Choquette D, et al. (2013) Total knee replacement as a knee osteoarthritis outcome: predictors derived from a 4-year long-term observation following a randomized clinical trial using chondroitin sulfate. Cartilage 4: 219-226.

76. Ganguly A (2018) Topical phytotherapy is the nobel approach for revision of total knee replacement: a unique case study. J Orthopedics Rheumatol 5: 1-5. 